\title{
Floristics and life-forms along a topographic gradient, central-western Ceará, Brazil
}

\author{
Florística e formas de vida ao longo de um gradiente topográfico no centro-oeste \\ do estado do Ceará, Brasil
}

\author{
Francisca Soares de Araújo ${ }^{1,2}$, Rafael Carvalho da Costa ${ }^{1}$, Jacira Rabelo Lima ${ }^{1}$, \\ Sandra Freitas de Vasconcelos ${ }^{1}$, Luciana Coe Girão ${ }^{1}$, Melissa Souza Sobrinho ${ }^{1}$, \\ Morgana Maria Arcanjo Bruno ${ }^{1}$, Sarah Sued Gomes de Souza ${ }^{1}$, Edson Paula Nunes ${ }^{1}$, \\ Maria Angélica Figueiredo ${ }^{1}$, Luiz Wilson Lima-Verde ${ }^{1}$ \& Maria Iracema Bezerra Loiola ${ }^{1}$
}

\begin{abstract}
To test whether the flora is organized in discrete or continuous units along a topographic gradient, three physiognomies were assessed on different soil classes in a semi-arid region of northeastern Brazil: caatinga (xeric shrubland) at altitudes from 300 to $500 \mathrm{~m}$, deciduous forest at altitudes from 500 to $700 \mathrm{~m}$ and carrasco (deciduous shrubland) at $700 \mathrm{~m}$. In each physiognomy a species inventory was carried out, and plants were classified according to life- and growth-forms. Species richness was higher in the deciduous forest (250) than in the carrasco (136) and caatinga (137). The caatinga shared only a few species with the carrasco (6 species) and the deciduous forest (18 species). The highest species overlap was between the deciduous forest and the carrasco (62 species). One hundred and four species occurred only in the caatinga, 161 only in the deciduous forest and 59 only in the carrasco. Woody species predominated in physiognomies on sedimentary soils with latosol and arenosol: 124 species occurred in the deciduous forest and 68 in the carrasco. In the caatinga on crystalline basement relief with predominance of planosol, herbs showed the highest species richness (69). Comparing the biological spectrum of Brazilian plant life-forms, the caatinga stood out with higher proportion of therophytes and chamaephytes. Considering the flora of the three phytophysiognomies studied here, we can affirm that the caatinga is a discrete floristic unit.
\end{abstract}

Key words: vegetation classification, biological spectrum, growth-form, phytoclimate, plant community.

\section{Resumo}

Para verificar se a composição florística constitui unidades discretas ou contínuas ao longo de um gradiente topográfico foram analisadas três fitofisionomias (caatinga sobre altitudes de 300 a $500 \mathrm{~m}$, floresta decídua sobre altitudes de 500 a $700 \mathrm{~m}$ e carrasco sobre atitudes de $700 \mathrm{~m}$ ) sobre classes de solos distintas no semiárido setentrional do Nordeste do Brasil. Em cada fisionomia foi realizado o levantamento das espécies, as quais foram classificadas em formas de vida e de crescimento. A riqueza de espécies foi maior na floresta decídua (250) do que no carrasco (136) e na caatinga (137). A caatinga apresentou poucas espécies em comum com as fitofisionomias de carrasco ou de floresta decídua (6 e 18 espécies). A maior sobreposição de espécies ocorreu entre a floresta decídua e o carrasco, 62 espécies. Foram exclusivas da caatinga, floresta decídua e do carrasco, 104, 161 e 59 espécies, respectivamente. Quanto às formas de crescimento, nas fisionomias sobre relevo sedimentar com Latossolo e Arenosolo predominaram espécies lenhosas: 124 na floresta decídua e 68 no carrasco. Na caatinga sobre relevo do embasamento cristalino com predominância de Planossolo, a maior riqueza de espécies (69) foi de ervas. Na análise comparativa do espectro biológico com outras formações brasileiras, o de caatinga se destacou dos demais, constituindo uma unidade individualizada pela maior proporção de terófitos e caméfitos. Em relação à flora das três físionomias, objeto deste estudo, pode-se afirmar que a da caatinga representa uma unidade discreta.

Palavras-chave: classificação de vegetação; espectro biológico; forma de crescimento; fitoclima, comunidade vegetal.

'Universidade Federal do Ceará, Depto. Biologia, Centro de Ciências, bloco 906, Campus do Pici, 60455-760, Fortaleza, CE, Brazil.

${ }^{2}$ Correponding author: tchesca@ufc.br 


\section{Introduction}

At a global scale, the main environmental variables used to classify vegetation are climate zones. A group of similar vegetation types that occur in similar climate zones in different continents is known as a vegetation-type or biome (Whittaker 1975, 1978a, b; Box \& Fujiwara 2005).

Changes in topography or microclimate can affect the biology of the vegetation, leading to particularities that can be detected only at a local scale (Spellerberg \& Sawyer 1999). Gradual changes in climate related to topography or to distance from the ocean, at a small scale, result in continuous vegetation units, which makes a classification based on floristic attributes difficult. However, when a climate variable is associated with different soil types, the regional flora may be discontinuously distributed, forming discrete communities, whose limits, along a topographic gradient, can be determined by an analysis of floristic composition and of the main growth- or life-forms of the plant species (Whittaker 1975; Box \& Fujiwara 2005).

To describe community types it is necessary to characterize plant forms, since physiognomy results from the dominant forms that compose a community (Whittaker 1975). Classes or types of plant forms are called growth-forms; this classification usually does not correspond to the categories used by taxonomists to classify plants. Height, woody or herbaceous habit, stem form, leaf form and intensity of leaf deciduousness are characteristics used to define the following types of growth-forms (Whittaker 1975): trees, shrubs, lianas, epiphytes, herbs and thallophytes.

Instead of using a system of multiple characteristics such as the growth-form system proposed by Whittaker (1975), the life-form system of Raunkiaer (1934) is based on a single characteristic: the relationship between the position of the perennial tissue (meristem), which remains inactive during the winter or dry season, and the growth surface. The life-form of a species represents a set of life history characteristics selected by the environment. Raunkiaer (1934) classified plants into five life-forms: phanerophytes, chamaephytes, hemicryptophytes, cryptophytes and therophytes.

The world spectrum, or normal spectrum, was calculated by Raunkiaer (1934) based on a representative sample of all the vascular flora of the world. From that sample, the patterns recorded in different directions reflect environmental effects, especially related to climate, on plant adaptations observed in a community (Raunkiaer 1934). Hence, whereas the growth-form classification is used to characterize community structure (because some forms are dominant or more conspicuous), the lifeform spectrum describes environmental adaptations of the species that compose that community (Whittaker 1975; Raunkiaer 1934). Indirectly, this system provides information on local seasonality. According to Whittaker (1975), life-forms are not a structural attribute, but a floristic attribute: when the number of species is converted into percentage of life-forms, this percentage would represent the spectrum of life-forms in this community or geographic area. The fact that a given community is characterized by particular life-forms indicates species convergence toward certain environmental conditions; and this represents a functional attribute of the community.

In the present study, we assessed life-forms, growth-forms and floristic composition of three neighboring physiognomies that occur under different climates, soils and topographies. These community attributes were determined for an area located in the semi-arid region of northeastern Brazil, which comprises two geomorphological units: sedimentary basin and crystalline basement.

Based on these data, we tested the following predictions: i) the floras of the two geomorphological units are different, and constitute two discrete units; ii) the life-form spectrum varies according to altitude and soil type, probably as a consequence of differences in water availability, resulting mainly in the occurrence of phanerophytes in the sedimentary basin and of therophytes in the crystalline basement.

\section{Material and Methods}

\section{Location and environmental} characterization of the study area

Serra das Almas Natural Reserve covers an area of 5,646 ha, and is located between the coordinates $5^{\circ} 15^{\prime}-5^{\circ} 00^{\prime} \mathrm{S}$ and $40^{\circ} 15^{\prime}-41^{\circ} 00^{\prime} \mathrm{W}$ (Fig. 1). The study area has three physiognomies: i) caatinga (xeric shrubland) with an area of 17.10 $\mathrm{km}^{2}(29.19 \%)$, ii) seasonal deciduous forest with an area of $27.93 \mathrm{~km}^{2}(47.64 \%)$ and iii) carrasco (deciduous shrubland)(Rougerie 1988) with an area of $11.79 \mathrm{~km}^{2}(20.12 \%)$.

The study area is located in two geomorphological units: i) the crystalline basement complex, with flat to slightly undulating relief and 


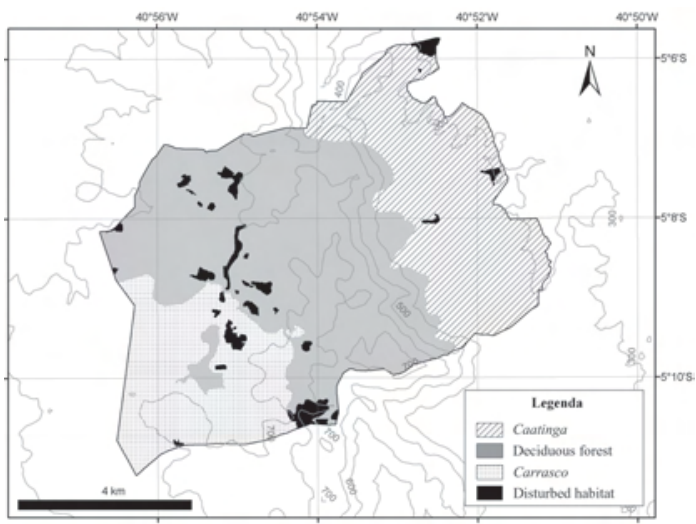

Figure 1 - Location of Serra das Almas Natural Reserve, Crateús, state of Ceará, Brazil.

low altitude (c. $400 \mathrm{~m}$ ) and ii) the Meio Norte sedimentary basin, on its eastern margin, which forms an asymmetric cuesta, known as Ibiapaba Plateau (altitudes between 500 and $700 \mathrm{~m}$ ).

The caatinga occurs in the crystalline basement complex, where the dominant classes of soils are: Solodic Planosol, Solodized Solonetz (natric Planosols) and Lithic soils (Lithic Neosols) at altitudes that vary from 300 to $500 \mathrm{~m}$.

In the Meio Norte sedimentary basin, on Ibiapaba Plateau, the Latosol occurs on the eastern hogback and quartz sand (quartzarenic neosols) on the top and backside (Brasil 1972). The deciduous forest occurs on the eastern hogback of the plateau, on Latosol, at altitudes between 500 and $700 \mathrm{~m}$. The carrasco is present on the backside of the plateau, on quartz sand, at altitudes of ca. $700 \mathrm{~m}$. We emphasize that the Ibiapaba Plateau is a 'cuesta', with higher asymmetry in its southern part, our study area, where there is no top, but an inverted V-shaped topography where the leeward on the backside exhibits a smooth declivity.

Climate data were not available, because there are no meteorological or pluviometric stations located on the cuesta, top and immediate backside sites on the southern part of the Ibiapaba Plateau, our study area.

\section{Floristic inventory}

The flora of Serra das Almas Natural Reserve was extensively sampled from 1999 to 2004, in several projects: reserve management plan; longterm ecological research programs - Site Caatinga/ CNPq/PELD; Instituto do Milênio do Semiárido-
IMSEAR; Biodiversity inventories - Caatinga (PROBIO-MMA) and Edital Universal do CNPq / 476285/2003-8. In these studies, branches of angiosperms (five duplicates) in reproductive phase (flower buds, flowers and/or fruits) were collected on trails and inside the best-conserved fragments of each physiognomy. Vouchers were deposited in the Prisco Bezerra Herbarium (EAC), of Universidade Federal do Ceará. Botanical identification was carried out using analytical keys (Freire 1983; Barroso et al. 1978, 1984, 1986) and by comparison with the material present in the EAC Herbarium or, when necessary, by consulting specialists. The classification used was APG III (2009). Species names were updated considering the synonymy of Missouri Botanical Garden (Tropicos.org 2009); names and/or abbreviations of species authors were written in accordance with Brummitt \& Powell (1992).

\section{Growth- and life-forms}

Each species was classified into growth-forms following Whittaker (1975).

The classification of each species in life-forms was done based on the protection level of growing tips and on the reduction of the aerial part during the unfavorable season, following Raunkiaer (1934, see also Cain 1950; Mueller-Dombois \& Ellenberg 1974): therophytes (Th), cryptophytes (Cr), hemicryptophytes $(\mathrm{H})$, chamaephytes $(\mathrm{Ch})$ and phanerophytes $(\mathrm{Ph})$. Woody lianas and cacti were considered as phanerophytes and non-woody lianas were classified according to the level of reduction of their aerial part during the dry season (according to Raunkiaer 1934).

\section{Data analysis}

Floristic data were organized as a list with families, species, vernacular names, life and growthforms, physiognomy and collectors. We calculated species and family richness for the whole dataset and by physiognomy. To compare the richest families between physiognomies, we used histograms with the ten richest families in descending order.

Floristic overlap between physiognomies was analyzed by calculating the frequency of species and families in overlapping classes: occurrence in all physiognomies, in pairs of physiognomies (caatinga/carrasco, caatinga/deciduous forest, carrasco/deciduous forest), and restricted to each physiognomy (caatinga, carrasco or deciduous forest). Results are presented in histograms. 
To test for differences in the composition of life-forms among physiognomies, we calculated the life-form spectrum, which is the proportion of species of each life-form. We determined which lifeform characterized each physiognomy by comparing our results with the normal spectrum proposed by Raunkiaer (1934). This spectrum represents the world flora and was used here as null hypothesis. At first, we tested for differences between the obtained and the normal spectrum using a $\chi^{2}$ test (Vieira 2004). When differences were significant, we calculated the relative contribution of each life-form's deviation to the computed $\chi^{2}$ statistic. The life-form with higher contribution in each test was considered as characteristic of the physiognomy where it occurs.

To test for similarities with other Brazilian vegetation types (in terms of life-forms), we compiled studies with spectra determined for Brazilian physiognomies (Tab. 1). We kept the names used by each author for the vegetation types of each study. To facilitate comparison, we used only the five main life-form classes of Raunkiaer (1934). Hence, epiphytes and woody lianas were included in the class phanerophytes, saprophytes in cryptophytes, and aerophytes in chamaephytes. We compared the life-form spectra found in Serra das Almas Natural Reserve with those from other studies with a detrended correspondence analysis - DCA (Jongman et al. 1995; Batalha \& Martins 2002); results were expressed in ordination diagrams with scores of each study and of each life-form.

\section{Results}

We recorded 419 species/morphospecies from 72 families (Annex 1). Families (55) and species richness (250) were higher in the deciduous forest. Richness values of the carrasco (46 and 136) and caatinga (44 and 137) were similar to each other and lower than in the deciduous forest.

Fabaceae (86 species), Euphorbiaceae (38 species) and Convolvulaceae (22 species) were the richest plant families in Serra das Almas Natural Reserve. The richest families were different among physiognomies (Fig. 2). The exception was the family Fabaceae, which had the highest number of species in all three physiognomies (Fig. 2). However, the representativeness of subfamilies varied, with higher richness of Papilionoidae in the deciduous forest ( 25 species) and of Caesalpinioidae in the caatinga (12 species) and carrasco (15 species).
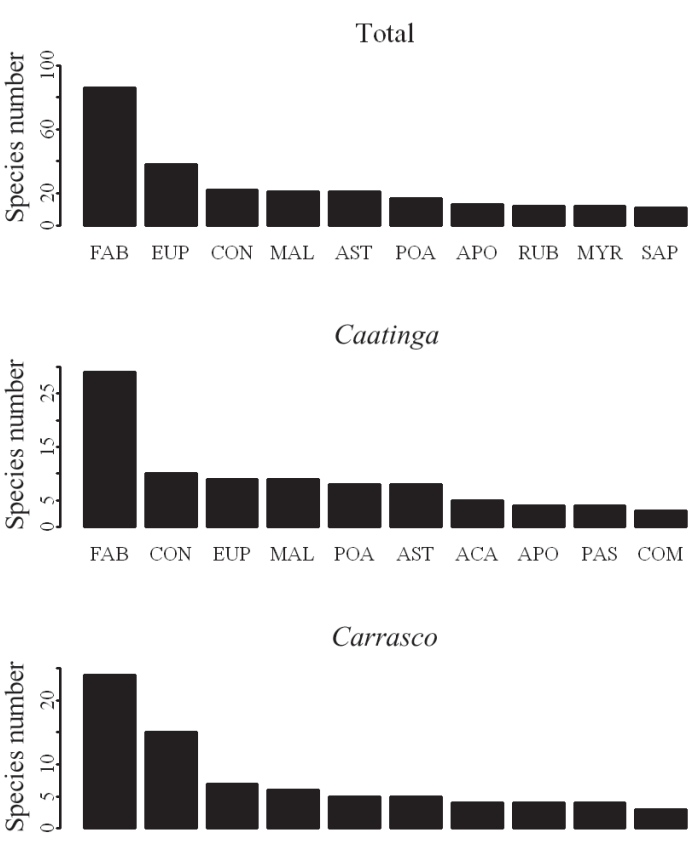

FAB EUP MYR ACA LAM RUB APO AST MAP BRO

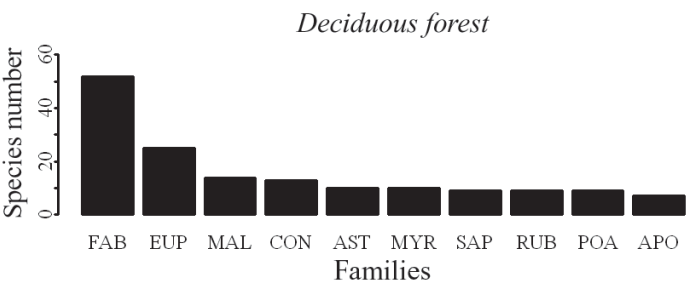

Figure 2-Species-richestfamilies in the three physiognomies of Serra das Almas Natural Reserve, Crateús, state of Ceará, Brazil. Abbreviations for families: FAB-Fabaceae, EUPEuphorbiaceae, CON- Convolvulaceae, MAL- Malvaceae, AST- Asteraceae, POA-Poaceae, APO-Apocynaceae, RUB - Rubiaceae, MYR-Myrtaceae, SAP-Sapindaceae, ACA-Acanthaceae, PAS-Passifloraceae, COMCommelinaceae, LAM-Lamiaceae, MAP-Malpighiaceae, BRO-Bromeliaceae.

Family overlap was about one third among all physiognomies (Fig. 3). However, the carrasco and the deciduous forest shared the highest number of families, and had the highest (carrasco) and lowest (deciduous forest) number of exclusive families (Fig. 3). Species overlap was low, as only nine out of 419 species occurred in all physiognomies (Fig. 3 ). The carrasco and the deciduous forest had higher floristic affinity with each other, since they shared more species $(15 \%)$ and both had low overlap with the caatinga ( $1.3 \%$ overlap with carrasco and $4.2 \%$ with deciduous forest - Fig. 3). 
Table 1 - Life-form spectra used for comparisons in a detrended correspondence analysis (DCA). Life-forms: Th - therophytes, $\mathrm{Cr}$ - cryptophytes, $\mathrm{H}$ - hemicryptophytes, $\mathrm{Ch}$ - chamaephytes, $\mathrm{Ph}$ - phanerophytes.

\begin{tabular}{|c|c|c|c|c|c|c|c|c|}
\hline Vegetation type & Abbreviation & Site & Reference & Th & $\mathrm{Cr}$ & $\mathbf{H}$ & $\mathbf{C h}$ & $\mathbf{P h}$ \\
\hline caatinga & caa & Sa. das Almas, Crateús, CE & This study & 47,9 & 1,4 & 6,3 & 18,1 & 26,4 \\
\hline carrasco & carr & Sa. das Almas, Crateús, CE & This study & 17,2 & 3,4 & 3,4 & 17,9 & 57,9 \\
\hline deciduous forest & fl dec & Sa. das Almas, Crateús, CE & This study & 14,6 & 2,6 & 2,2 & 22,5 & 58,1 \\
\hline caatinga & caa & Faz. Não me Deixes, Quixadá, CE & Costa et al. (2007) & 42,9 & 2,3 & 12,8 & 15,8 & 26,3 \\
\hline cerradofechado & cer fec & Brasília, DF & Ratter (1980) in Batalha \& Martins (2002) & 0,7 & 1,8 & 44,9 & 13,5 & 39,1 \\
\hline cerrado aberto & cer $a b$ & PARNA das Emas, GO & Batalha \& Martins (2002) & 3,7 & 2 & 49,9 & 12,8 & 31,6 \\
\hline cerrado aberto & cer $a b$ & Lagoa Santa, MG & Warming (1892) in Batalha \& Martins (2002) & 4,6 & 5,4 & 55,1 & 6,1 & 28,8 \\
\hline cerrado aberto & cer $a b$ & Mojiguaçu, SP & Mantovani (1983) in Batalha \& Martins (2002) & 7,8 & 2,1 & 47 & 12,2 & 30,9 \\
\hline cerradofechado & cer fec & Pirassununga, SP & Batalha et al (1997) in Batalha \& Martins (2002) & 5,6 & 1,1 & 36,1 & 17,1 & 40,1 \\
\hline cerradofechado & cerfec & Sta. Rita do Passa Quatro, SP & $\begin{array}{l}\text { Batalha \&Mantovani (2001) } \\
\text { in Batalha \& Martins (2002) }\end{array}$ & 6,7 & 0,8 & 30 & 17,2 & 45,3 \\
\hline pluvial forest & $\mathrm{fl} \mathrm{pl}$ & Alto do Palmital, Foz do Iguaçu, PR & Cain et al. (1956) & 0 & 3 & 11 & 6 & 80 \\
\hline pluvial forest & $\mathrm{fl} \mathrm{pl}$ & Caiobá, PR & Cain et al. (1956) & 0 & 3 & 3 & 7 & 87 \\
\hline pluvial forest & $\mathrm{fl} \mathrm{pl}$ & Mucambo, Belém, PA & Cain et al. (1956) & 0 & 0,9 & 2,8 & 0,9 & 95,4 \\
\hline temperate forest & fl temp & Horto Botânico, Pelotas, RS & Cain et al.(1956) & 5 & 5 & 16 & 4 & 70 \\
\hline cerradão & cerradão & Águas de Sta. Barbara, SP & Meira Neto et al. (2007) & 0 & 0 & 4 & 1,3 & 94,7 \\
\hline cerrado sensu strictu & cerss & Águas de Sta. Barbara, SP & Meira Neto et al. (2007) & 0 & 2,8 & 10,7 & 9,6 & 77 \\
\hline campo cerrado & cp cer & Águas de Sta. Barbara, SP & Meira Neto et al. (2007) & 0 & 6,4 & 19,2 & 14,1 & 60,3 \\
\hline campo sujo & cp sj & Águas de Sta. Barbara, SP & Meira Neto et al. (2007) & 0 & 7,9 & 31,8 & 41,3 & 19,1 \\
\hline campo limpo & $\mathrm{cllp}$ & Águas de Sta. Barbara, SP & Meira Neto et al. (2007) & 5 & 0 & 32 & 34 & 14 \\
\hline restinga & res & Itamaracá. PE & Almeida JR et al. (2007) & 16,8 & 5,3 & 8 & 19,5 & 50,4 \\
\hline inselberg vegetation & inselb & Quixadá, CE & Araújo et al. (2008) & 44,2 & 2,6 & 13 & 15,6 & 24,7 \\
\hline cerrado sensu strictu & cer ss & Itirapina, SP & Batalha \& Martins (2004) & 1,8 & 1,8 & 18,6 & 11,5 & 66,4 \\
\hline caatinga & caa & Betânia, PE & Costa et al. (2009) & 40,5 & 1,1 & 14,6 & 18 & 25,8 \\
\hline restinga & res & Caravela, BA & Meira Neto et al. (2005) & 9 & 0 & 14,9 & 23,9 & 52,2 \\
\hline restinga & res & Mucurí, BA & Meira Neto et al. (2005) & 7,5 & 0 & 28,3 & 24,5 & 39,6 \\
\hline
\end{tabular}

Note: caatinga $=$ xeric shrubland; carrasco $=$ deciduous shrubland; cerrado sensu stricto $=$ savanna; cerrado fechado $=$ dense savanna; cerrado aberto $=$ open savanna; campo cerrado $=$ grassland with scatered shrubs; campo sujo = grassland with scatered shrubs; campo limpo $=$ grassland; cerradã $o=$ tall woodland savanna; resting $a=$ sandy coastal plains. 


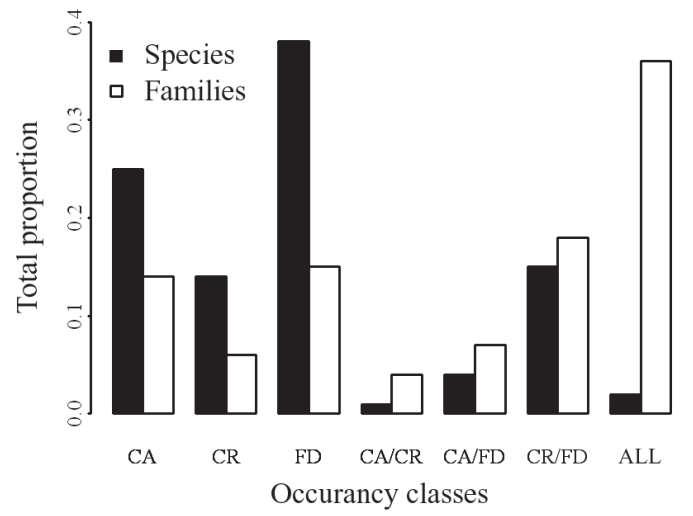

Figure 3 - Proportion of families (white) and species (black) occurring in one, two or in all physiognomies (CA - caatinga, $\mathrm{CR}$ - carrasco, $\mathrm{DF}$ - deciduous forest) of Serra das Almas Natural Reserve, Crateús, state of Ceará, Brazil.

In the physiognomies on sedimentary relief, woody species (shrubs and trees) predominated, totaling 124 in the deciduous forest and 68 in the carrasco. In the caatinga, on the crystalline basement, the highest species richness (69) was represented by herbs.

The life-form spectra of the studied physiognomies differed significantly from the normal spectrum (caatinga: $\chi^{2}=159.33 \mathrm{p}<0.01 \mathrm{df}=4$; carrasco $\chi^{2}=49.07 \mathrm{p}<0.01 \mathrm{df}=4$; deciduous forest $\left.\chi^{2}=120, \mathrm{p}<0.01 \mathrm{df}=4\right)$. In general, the carrasco and the deciduous forest exhibited similar proportions of species of each life-form, whereas the caatinga exhibited a different spectrum (Fig. 4). Therophytes, hemicryptophytes and chamaephytes were the predominant life-forms in the caatinga (69\%), carrasco (53\%) and deciduous forest (46\%), respectively; thus, they characterize each physiognomy.

In the comparisons of life-form spectra among physiognomies of Serra das Almas Natural Reserve with other Brazilian vegetation types, the two first axes of the DCA corresponded to over $60 \%$ of the total inertia: $49.68 \%$ on the first axis and $13.30 \%$ on the second. In the ordination diagram three groups of life-form spectra stood out: i) spectra with scores next to the ones of phanerophytes, ii) of cryptophytes and iii) of chamaephytes and therophytes (Fig. 5). The life-form spectra of the carrasco and the deciduous forest in Serra das Almas Natural Reserve nearly overlapped in the ordination space, in group 2, which also comprises the restinga and cerrado spectra (Fig. 5). In this

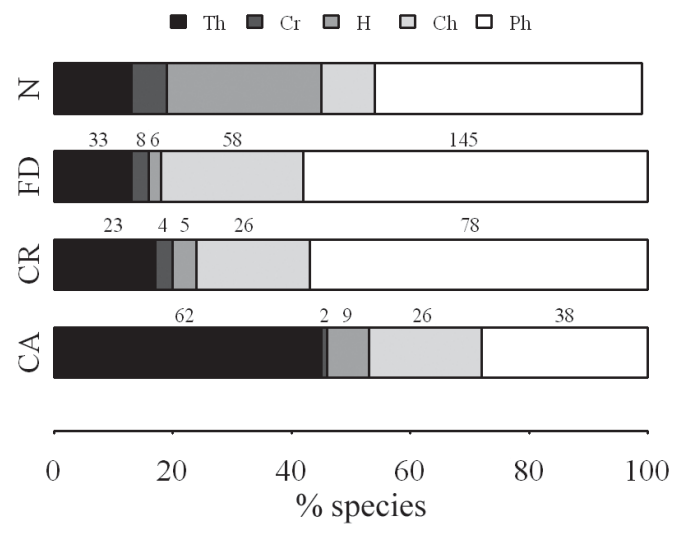

Figure 4 - Life-form spectra of the three physiognomies (CA-caatinga, $\mathrm{CR}$ - carrasco, $\mathrm{DF}$ - deciduous forest) of Serra das Almas Natural Reserve, Crateús, state of Ceará, Brazil, compared to Raunkiaer's normal spectrum (N). Values over each physiognomy bar indicate the number of species of each life-form. Species percentages of each life-form are expressed by the width of the bar. Life-forms: therophyte (Th), cryptophyte $(\mathrm{Cr})$, hemicryptophyte $(\mathrm{H})$, chamaephyte $(\mathrm{Ch})$, phanerophyte $(\mathrm{Ph})$.

group, carrasco and deciduous forest exhibited scores close to those of restinga and different from those of cerrado, apparently because of the lower proportion of cryptophytes (Fig. 5). The caatinga composed a well-defined group, which comprised spectra of other caatinga studies, including vegetation on inselbergs. This group is associated with higher proportion of chamaephytes and therophytes (Fig. 5).

\section{Discussion}

In general, in the semi-arid region of northeastern Brazil, areas with higher annual average rainfall associated with higher altitudes exhibit higher species richness (Lima et al. 2009; Araújo et al. 2007; Ferraz et al. 1998; Gomes 1980). This pattern was also observed in the physiognomies of deciduous forest and carrasco, both located at higher altitudes than the caatinga in Serra das Almas Natural Reserve. Besides, deciduous vegetation on sedimentary areas, even with rainfall indexes similar to the caatinga area of the crystalline basement, have been pointed out in general as having higher species richness (Silva et al. 2003), though there are some exceptions (Rodal et al. 1998; Pereira et al. 2002). These exceptions show that being sedimentary alone does not result in higher species richness; other 


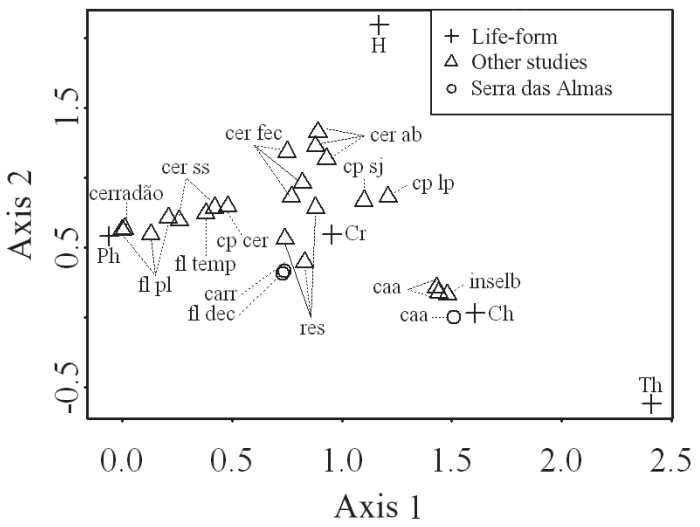

Figure 5 - Ordination diagram of the detrended correspondence analysis (DCA), with scores of life-forms and compiled inventories, including the physiognomies of Serra das Almas Natural Reserve. Abbreviations for vegetation types follow Table 1. Life-forms: therophyte (Th), cryptophyte ( $\mathrm{Cr})$, hemicryptophyte $(\mathrm{H})$, chamaephyte $(\mathrm{Ch})$, phanerophyte $(\mathrm{Ph})$.

factors must also be considered, such as the position of the hogback, level of desiccation of the relief and physiochemical composition of the soil. The deciduous forest of Serra das Almas Natural Reserve is located on the windward side, between $500 \mathrm{~m}$ and $700 \mathrm{~m}$, whereas the carrasco, though located at a higher altitude about $700 \mathrm{~m}$, is located on the leeward side and on sandier soils, which results in a physiognomy of lower height, smaller and slender plants and lower richness than in the deciduous forest.

Concerning the herbaceous component of the Brazilian semi-arid flora, studies carried out in the inter-plateau depression of the crystalline complex indicate that the highest richness of the caatinga sensu stricto is in the herbaceous component (Sampaio 1995; Rodal et al. 2005; Costa et al. 2007; Mamede \& Araújo 2008). Comparatively, studies carried out in sedimentary formations recorded low richness of herbaceous flora (Rodal et al. 1999; Figueirêdo et al. 2000).

In Serra das Almas Natural Reserve, the floristic richness of woody species increased at high altitudes in areas of deciduous forest and carrasco, whereas the richness of herbaceous species decreased. The increase in richness of trees and shrubs with altitude seems to be a general pattern for vegetation of arid and semi-arid regions. In the Brazilian semi-arid region, the increase in richness of herbaceous growth-forms and decrease in woody growth-forms is related to the increase in aridity (lower rainfall and higher temperature). In previous studies, the replacement of non-woody life-forms by woody life-forms and the increase in richness along humidity gradients have been observed in arid areas (Pavón et al. 2000), tropical savannas (Williams et al. 1996), forests and temperate grasslands (Kovács-Lang et al. 2000).

Considering woody and herbaceous flora together, the deciduous forest on the sedimentary basin exhibited higher richness than the caatinga located on the crystalline basement. Potentially, there must be higher humidity in the air and soil resulting from the elevation; there must be also soils with permanent water availability in deep layers (latosols and quartz sands), which possibly contribute to the higher floristic richness observed.

Comparing the carrasco and the deciduous forest located in the same sedimentary basin, the latter exhibited higher richness. In this case, humidity seems to be an important factor: the deciduous forest is located on the cuesta and the carrasco on the immediate backside. On the backside the air is probably drier and wind speed is higher, which causes more desiccation. Besides, soil seems to play a role too, since carrasco soils are sandier (Araújo \& Martins 1999; Araújo et al. 1999).

Despite the high species richness found in the region of Ibiapaba Plateau, it is important to highlight the contribution of the non-woody component (herbs, subshrubs and herbaceous lianas) to the total species richness of each physiognomy. In the caatinga, on the crystalline basement, non-woody plants were responsible for most of the floristic richness, that is expected in arid and semi-arid climates, due to the predominance of therophytes in these environments. On the contrary, in the carrasco and in the deciduous forest, woody plants were responsible for the highest richness, since in more humid climates phanerophytes predominate.

Higher water availability favors the establishment of life-forms that do not need large reductions of the aerial shoot system during the unfavorable season (phanerophytes), which is a necessary strategy for the survival of most species in arid and semi-arid regions (see Raunkiaer 1934; van Rooyen et al. 1990; Kovács-Lang et al. 2000). In the case of Serra das Almas Natural Reserve, which is inserted in a semi-arid climatic domain, the increase in altitude may potentially favor high water availability on the windward side. Besides, soil must be taken into account, since there are two different 
geological units: lowlands of the crystalline basement and the Meio Norte sedimentary basin.

Herbaceous or sub-woody plants (herbs, subshrubs and herbaceous lianas) are the life-forms that exhibit the highest reduction of the aerial shoot system during the dry season (therophytes, cryptophytes, and hemicryptophytes; Raunkiaer 1934). The biological spectrum of the caatinga studied was characterized mainly by therophytes, a life-form characteristic of arid and semi-arid regions (Raunkiaer 1934; van Rooyen et al. 1990; Kovács-Lang et al. 2000). Indeed, among the three physiognomies studied, the caatinga occurs on shallow soils in the lowlands of the crystalline basement, where temperature is potentially higher and rainfall is potentially lower than in mountainrange areas, resulting in lower water availability. The physiognomies on the Ibiapaba plateau (carrasco and deciduous forest) must occur under lower water restrictions, since higher altitude contributes to the potential occurrence of higher rainfall and lower temperature, which favor phanerophytes, a life-form characteristic of sites with lower water restriction.

In addition to numeric differences in species richness, remarkable differences between the floristic complexes of each physiognomy were observed in the present study. The two main complexes (caatinga and carrasco + deciduous forest) are consistent with the soil types that occur in the area, resulting from the type of source rock. Although species overlap between deciduous forest and carrasco may be considered low (15\%), differences are even larger when compared with caatinga, whose overlap is only $4 \%$. Carrasco and deciduous forest are floristically more similar because both have a set of species that prefer sandy soil with low $\mathrm{pH}$, whereas caatinga differs from that floristic group by the presence of species typical of soils originated from the crystalline basement of the inter-plateau depression. The crystalline and sedimentary floras of northeastern Brazil also differ at a broader scale, as it was observed in analyses of data matrices created from local inventories, carried out in several areas of the Brazilian semi-arid region (Araújo et al. 1998a, b; Lemos \& Rodal 2002; Alcoforado-Filho et al. 2003; Araújo et al. 2005; Lima et al. 2009).

As Andrade-Lima (1981) emphasized, in the Brazilian semi-arid region, when the predominant variation is in climate, as observed in the two physiognomies studied in the Ibiapaba Plateau (the deciduous forest occurs on the windward side whereas the carrasco occurs on the leeward side), these do not form discrete units. They form a continuum represented by species overlap and by the same biological spectrum, as emphasized by Austin (2005).

When analyzing physiognomies on different geomorphological units, apart from the climate, the soil component may determine discrete units; communities that, according to Whittaker (1975), can be delimited by floristic composition and lifeforms, such is the case of the difference found between the caatinga and the complex deciduous forest + carrasco.

In the comparative analysis with the biological spectra from other Brazilian seasonal vegetation types, the discrimination of the caatinga by higher proportion of therophytes and chamaephytes shows that this vegetation is composed of species whose life-forms represent better the semi-arid climatic pattern, since the predominance of these life-forms is characteristic of vegetations of arid and semi-arid environments (Raunkiaer 1934; Cain 1950). The biological spectrum is similar to the spectrum of arid and semiarid climate zones of the world.

In summary, the two geomorphological units present in the study area have two distinct floristic complexes, characterized by the predominance of therophytes on the crystalline basement and of phanerophytes on the sedimentary basin. These results show that when implementing reserves in Brazilian semi-arid areas, abiotic local factors, such as soils and relief, must be taken into account, because these factors seem to reflect regional floristic variation. The environmental heterogeneity may result not only in high species diversity, but also in high functional diversity in the Brazilian semi-arid domain, which, in the present study, may be observed in differences in life-form spectra among the three physiognomies analyzed.

\section{Acknowledgements}

The non-governmental organization Associação Caatinga funded the management plan for the reserve, through which the floristic inventory of the area was carried out. Later, studies were carried out with funding from Ministério de Ciência e Tecnologia, long-term ecological research programs (CNPq/PELD - Pesquisa Ecológica de Longa Duração - site Caatinga), Instituto do Milênio do Semiárido (IMSEAR-MCT/CNPq), of Edital Universal do CNPq (proc. $n^{\circ} .476285 / 2003-8$ ) and PROBIO/MMA 
(Biodiversity inventories - Caatinga). Marcelo Oliveira Teles de Menezes helped us make Figure 1. Reviewers contributed for improving the final version of the manuscript.

\section{References}

Alcoforado-Filho, F.G.; Sampaio, E.V.S.B. \& Rodal, M.J.N. 2003. Florística e fitossociologia de um remanescente de vegetação caducifólia espinhosa arbórea em Caruaru, Pernambuco. Acta Botanica Brasilica 17: 287-303.

Almeida Jr., E.B; Pimentel, R.M.M. \& Zickel, C.S. 2007. Flora e formas de vida em uma área de restinga no litoral norte de Pernambuco, Brasil. Revista de Geografia 24: 19-34.

Andrade-Lima, D. 1981. The caatingas dominium. Revista Brasileira de Botânica 4: 149-153.

APG III. 2009. An update of the Angiosperm Phylogeny Group classification for the orders and families of flowering plants: APG III. Botanical Journal of the Linnean Society 161: 105-121.

Araújo, F.S. \& Martins, F.R. 1999. Fisionomia e organização da vegetação do carrasco no planalto da Ibiapaba, estado do Ceará. Acta Botanica Brasilica 13: 1-14.

Araújo, F.S.; Martins, F.R. \& Shepherd, G.J. 1999. Variações estruturais e florísticas do carrasco no planalto da Ibiapaba, estado do Ceará. Revista Brasileira de Biologia 59: 663-678.

Araújo, F.S.; Gomes, V.S.; Silveira, A.P.; Figueiredo, M.A.; Oliveirra, R.F.; Bruno, M.M.A.; Lima-Verde, L.W.; Silva, E.F.; Otutumi, A.T. \& Ribeiro, K.A. 2007. Efeito da variação topoclimática na fisionomia e estrutura da vegetação da serra de Baturité, Ceará. In: Oliveira, T.S. \& Araújo, F.S. (orgs.). Diversidade e conservação da biota da serra de Baturité, Ceará. Seri\&A Gráfica, Fortaleza. Pp. 73-136.

Araújo, F.S.; Rodal, M.J.N.; Barbosa, M.R.V. \& Martins, F.R. 2005. Repartição da flora lenhosa no domínio da caatinga. In: Araújo, F.S.; Rodal, M.J.N. \& Barbosa M.R.V. (orgs.). Análise das variações da biodiversidade do bioma caatinga: suporte a estratégias regionais de conservação. Ministério do Meio Ambiente, Brasília. Pp. 15-33.

Araújo, F.S.; Sampaio, E.V.S.B.; Figueiredo, M.A.; Rodal, M.J.N. \& Fernandes, A.G. 1998a. Composição florística da vegetação do carrasco, Novo Oriente, CE. Revista Brasileira de Botânica 21: 105-116.

Araújo, F.S.; Sampaio, E.V.S.B.; Rodal, M.J.N. \& Figueiredo, M.A. 1998b. Organização comunitária do componente lenhoso de três áreas de carrasco em Novo Oriente - CE. Revista Brasileira de Biologia 58: 85-95.

Araújo, F.S.; Oliveira, R.F. \& Lima-Verde, L.W. 2008. Composição, espectro biológico e síndromes de dispersão da vegetação de uma inselbergue no domínio da caatinga, Ceará. Rodriguésia 59: 659-671.
Austin, M.P. 2005. Vegetation and environment: discontinuities and continuities. In: Maarel, E.V.D. (ed.). Vegetation ecology. Blackwell Publishing, Oxford. Pp. 52-84.

Barroso, G.M.; Guimarães, E.F.; Ichaso, C.L.F.; Costa, C.G.; Peixoto, A.L. \& Lima, H.C. 1978. Sistemática de angiospermas do Brasil. Vol. 1. EdUSP, São Paulo. 255p.

Barroso, G.M.; Guimarães, E.F.; Ichaso, C.L.F.; Costa, C.G.; Peixoto, A.L. \& Lima, H.C. 1984. Sistemática de angiospermas do Brasil. Vol. 2. UFV, Viçosa. 377p.

Barroso, G.M.; Guimarães, E.F.; Ichaso, C.L.F.; Costa, C.G.; Peixoto, A.L. \& Lima, H.C. 1986. Sistemática de angiospermas do Brasil. Vol. 3. UFV, Viçosa. 326p.

Batalha, M.A. \& Martins, F.R. 2002. Life-form spectra of Brazilian cerrado sites. Flora 197: 452-460.

Batalha, M.A. \& Martins, F.R. 2004. Floristic, frequency, and life-form spectra of a cerrado site. Brazilian Journal of Biology 64: 203-209.

Box, E.O. \& Fujiwara, K. 2005. Vegetation types and their broad-scale distribution. In: Maarel, E.V.D. (eds.). Vegetation ecology. Blackwell Publishing, Oxford. Pp. 106-128.

Brasil. 1972. Mapa exploratório-reconhecimento de solos: estado do Ceará, escala 1:600.000. SUDENE.

Brumitt, R.K. \& Powell, C.E. 1992. Authors of plant names. Richmond, Kew Royal Botanic Gardens. 732p.

Cain, S.A. 1950. Life forms and phytoclimate. Botanical Review 16: 1-32.

Cain, S.A.; Castro, G.M.O.; Pires, J.M. \& Silva, N.T. 1956. Application of some phytosociological techniques to Brazilian rain forest. American Journal of Botany 43: 911-941.

Costa, R.C.; Araújo, F.S. \& Lima-Verde, L.W. 2007. Flora and life-form spectrum in an area of deciduous thorn woodland (caatinga) in northeastern, Brazil. Journal of Arid Environments 68: 237-247.

Costa, K.C.; Lima, A.L.A.; Fernandes, C.F.M.; Silva, M.C.N.A.; Silva, A.C.B.L.\& Rodal, M.J.N. 2009. Flora vascular e formas de vida em um hectare de caatinga no nordeste brasileiro. Revista Brasileira de Ciências Agrárias 4: 48-54.

Ferraz, E.M.N.; Rodal, M.J.N.; Sampaio, E.V.S.B. \& Pereira, R.C.A. 1998. Variação florística ao longo de um gradiente altitudinal no alto vale do Pajeú, Pernambuco. Revista Brasileira de Botânica 21: 7-13.

Figueirêdo, L.S.; Rodal, M.J.N. \& Melo, A.L. 2000. Florística e fitossociologia de uma área de vegetação arbustiva caducifólia espinhosa no município de Buíque - Pernambuco. Naturalia 25: 205-224.

Freire, C.V. 1983. Chaves analíticas para a determinação das famílias das plantas pteridófitas, gimnospermas e angiospermas brasileiras ou exóticas cultivadas no Brasil. v. CCC. Coleção Mossoroense, Mossoró. 366p.

Gomes, M.A.F. 1980. A vegetação dos Cariris Velhos, no estado da Paraíba. Vegetalia - escritos e documentos 14 (UNESP). 
Jongman, R.H.G.; Ter Braak, C.J.F. \& van Tongeren, O.F.R. 1995. Data analysis in community and landscape ecology. Cambrige University Press, Cambridge. 299p.

Kovács-Lang, E.; Kroel-Dulay, G.; Kertész, M.; Fekete, G.; Bartha, S.; Mika, J.; Dobi-Wantuch, I.; Redei, T.; Rajkai, K. \& Hahn, I. 2000. Changes in composition of sand grasslands along a gradient in Hungary and implications for climate change. Phytocoenologia 30: 385-407.

Lemos, J.R. \& Rodal, M.J.N. 2002. Fitossociologia do componente lenhoso de um trecho da vegetação de caatinga no parque nacional da Serra da Capivara, Piauí, Brasil. Acta Botanica Brasilica 16: 23-22.

Lima, J.R.; Sampaio, E.V.S.B.; Rodal, M.J.N. \& Araújo, F.S. 2009. Composição florística da floresta estacional decídua montana da Serra das Almas, Ceará, Brasil. Acta Botanica Brasilica 23: 756-763.

Mamede, M.A. \& Araújo, F.S. 2008. Effects of slash and burn practices on a soil seed bank of caatinga vegetation in Northeastern Brazil. Journal of Arid Environments 72: 458-470.

Meira Neto, J.A.A.; Souza A.L.; Lana, J.M. \& Valente, G.E. 2005. Composição florística espectro biológico e fitofisionomia da vegetação de muçununga nos municípios de Caravelas e Mucurí, Bahia. Revista Árvore 29: 139-150.

Meira Neto, J.A.A.; Martins, F.R. \& Valente, G.E. 2007. Composição florística espectro biológico na Estação Ecológica de Santa Bárbara, estado de São Paulo, Brasil. Revista Árvore 315: 907-922.

Mueller-Dombois, D. \& Ellenberg, H. 1974. Aims and methods of vegetation ecology. John Willey and Sons, New York. 547p.

Pavón, N.P.; Hernandez-Trejo, H. \& Rico-Gray, V. 2000. Distribution of life forms along an altitudinal gradient in the semi-arid valley of Zapotitlán, Mexico. Journal of Vegetation Science 11: 39-42.

Pereira, I.M.; Andrade, L.A.; Barbosa, M.R.V. \& Sampaio, E.V.S.B. 2002. Composição florística e análise fitossociológica do componente arbustivoarbóreo de um remanescente florestal no agreste Paraibano. Acta Botanica Brasilica 16: 241-369

Raunkiaer, C. 1934. The life forms of plants and statistical plant geography. Clarendon Press, Oxford. 632p.

Rodal, M.J.N.; Andrade, K.V.A.; Sales, M.F. \& Gomes, A.P.S. 1998. Fitossociologia do componente lenhoso de um refúgio vegetacional no município de Buíque, Pernambuco. Revista Brasileira de Biologia 58: 517-526.
Rodal, M.J.N.; Lins e Silva, A.C.B.; Pessoa, L.M. \& Cavalcanti, A.D.C. 2005. Vegetação e flora fanerogâmica da área de Betânia, Pernambuco. In: Araújo, F.S.; Rodal, M.J.N. \& Barbosa, M.R.V. (orgs.). Análise das variações da biodiversidade do bioma caatinga: suporte a estratégias regionais de conservação. Ministério do Meio Ambiente, Brasília. Pp. 91-119.

Rodal, M.J.N.; Nascimento, L.M. \& Melo, A.L. 1999. Composição florística de um trecho de vegetação arbustiva caducifólia, no município de Ibimirim, PE, Brasil. Acta Botanica Brasilica 13: 1: 15-28.

Rougerie, G. 1988. Géographie de la biosphére. Armand Colin Editeur, Paris. 288p.

Sampaio, E.V.S.B. 1995. Overview of the Brazilian caatinga. In: Bullock, S.H.; Mooney, H.A. \& Medina, E. Seasonally dry tropical forest. Cambridge University Press, Cambridge. Pp. 35-63.

Silva, R.A.; Santos, A.M.M. \& Tabarelli, M. 2003. Riqueza e diversidade de plantas lenhosas em cinco unidades de paisagem da Caatinga. In: Leal, I.R.; Tabarelli, M. \& Silva, J.M.C. (eds.). Ecologia e conservação da caatinga. Ed. Universitária da UFRPE, Recife. Pp. 337-365.

Spellerberg, I.F. \& Sawyer, J.W.D. 1999. An introduction to applied biogeography. Cambridge University Press, Cambridge. 243p.

van Rooyen, M.W.; Theron, G.K. \& Grobbelaar, N. 1990. Life forms and spectra of flora of Namaqualand, South Africa. Journal of Arid Environments 19: 133-145.

Vieira, S. 2004. Bioestatística, tópicos avançados - testes não-paramétricos, tabelas de contingência e análise de regressão. 2ed. Elsevier, Rio de Janeiro. 216p.

Whittaker, R.H. 1975. Communities and ecosytems. 2ed. Macmillan Publishing, New York. 385p.

Whittaker, R.H. 1978a. Approaches to classifying vegetation. In: Whittaker, R.H. (ed.). Classification of plant communities. Dr. W. Junk Publishers, The Hague. Pp 3-31.

Whittaker, R.H. 1978b. Dominace-types. In: Whittaker, R.H. (ed.). Classification of plant communities. Dr. W. Junk Publishers, The Hague. Pp. 65-79.

Williams, R.J.; Duff, G.A.; Bowman, D.M.J.S \& Cook, G.D. 1996. Variation in the composition and structure of tropical savannas as a function of rainfall and soil texture along a large-scale climatic gradient and soil texture in the Northern Territory, Australia. Journal of Biogeography 23: 747-756. 


\begin{tabular}{|c|c|c|c|c|c|c|c|}
\hline Families/species & Common name & FC & FV & $\mathbf{C A}$ & CR & DF & Collector \\
\hline \multicolumn{8}{|l|}{ Acanthaceae } \\
\hline Anisacanthus trilobus Lindau & pimentinha & sub & $\mathrm{Ch}$ & $\mathrm{x}$ & $\mathrm{x}$ & & F.S. Araújo, 1593 \\
\hline Justicia fragilis Wall. ex Clarke & & sub & $\mathrm{Ch}$ & & $\mathrm{x}$ & $\mathrm{x}$ & F.S. Araújo, 1490 \\
\hline Justicia strobilacea (Nees) Lindau & & $\operatorname{shr}$ & $\mathrm{Ph}$ & & $\mathrm{x}$ & $\mathrm{x}$ & F.S. Araújo, 1458 \\
\hline Justicia sp. & & $\operatorname{shr}$ & $\mathrm{Ph}$ & $\mathrm{x}$ & & & F.S. Araújo, 1539 \\
\hline Lophothecium sp. & & sub & $\mathrm{Ch}$ & & & $\mathrm{x}$ & M.S. Sobrinho, 124 \\
\hline Ruellia cf. bahiensis (Nees) Morong & & sub & $\mathrm{Ch}$ & & $\mathrm{x}$ & & F.S. Araújo, 1576 \\
\hline Ruellia paniculata $\mathrm{L}$. & melosa-de-bode, melosa & shr & $\mathrm{Ch}$ & $\mathrm{x}$ & $\mathrm{x}$ & & F.S. Araújo, 1547 \\
\hline Alstroemeria sp. & & her & $\mathrm{Cr}$ & & & $\mathrm{x}$ & F.S. Araújo, 1511 \\
\hline Bomarea edulis (Tussac) Herb. & & her & $\mathrm{Cr}$ & & & $\mathrm{x}$ & F.S. Araújo, 1442 \\
\hline \multicolumn{8}{|l|}{ Amaranthaceae } \\
\hline Alternanthera brasiliana (L.) Kuntze & $\begin{array}{l}\text { quebra-panela, } \\
\text { cabeça-branca }\end{array}$ & her & Th & $\mathrm{x}$ & $\mathrm{x}$ & $\mathrm{x}$ & F.S. Araújo, 1377 \\
\hline \multicolumn{8}{|l|}{ var. villosa (Moq.) Kuntze } \\
\hline Froelichia lanata Moench & & her & Th & $\mathrm{x}$ & & $\mathrm{x}$ & F.S. Araújo, 1400 \\
\hline Gomphrena demissa Mart. & & her & Th & & & $\mathrm{x}$ & F.S. Araújo, 1436 \\
\hline \multicolumn{8}{|l|}{ Amaryllidaceae } \\
\hline \multicolumn{8}{|l|}{ Anacardiaceae } \\
\hline Myracrodruon urundeuva Allemão & aroeira & tre & $\mathrm{Ph}$ & $\mathrm{x}$ & & & Probio, 400 \\
\hline
\end{tabular}




\begin{tabular}{lllll}
\hline Families/species & Common name & FC & FV & $\begin{array}{c}\text { Phytophysiognomy } \\
\text { CA }\end{array}$ \\
\hline
\end{tabular}

\section{Annonaceae}

Duguetia riedeliana $\mathrm{R}$. E. Fr.

Ephedranthus pisocarpus R. E. Fr.

Rollinia leptopetala $\mathrm{R}$. E. Fr.

\begin{tabular}{|c|c|c|c|c|c|c|}
\hline camucá & tre & $\mathrm{Ph}$ & & & $\mathrm{x}$ & Probio, 214 \\
\hline condurú & tre & $\mathrm{Ph}$ & & $\mathrm{x}$ & $\mathrm{x}$ & J.R. Lima, 16 \\
\hline bananinha & $\operatorname{shr}$ & $\mathrm{Ph}$ & & $\mathrm{x}$ & $\mathrm{x}$ & M.S. Sobrinho, 15 \\
\hline $\begin{array}{l}\text { pente-de-macaco, } \\
\text { cravo-de-cachorro }\end{array}$ & lia & $\mathrm{H}$ & $\mathrm{x}$ & $\mathrm{x}$ & $\mathrm{x}$ & F.S. Araújo, 1335 \\
\hline pereiro-branco & tre & $\mathrm{Ph}$ & $\mathrm{x}$ & & & F.S. Araújo, 1352 \\
\hline $\begin{array}{l}\text { canela-de-velho, } \\
\text { caneleiro }\end{array}$ & tre & $\mathrm{Ph}$ & & & $\mathrm{x}$ & J.R. Lima, 18 \\
\hline piquiá & tre & $\mathrm{Ph}$ & & & $\mathrm{x}$ & J.R. Lima, 19 \\
\hline pereiro-preto, pereiro & tre & $\mathrm{Ph}$ & $\mathrm{x}$ & & & Probio, 403 \\
\hline \multirow[t]{6}{*}{ piquiá } & tre & $\mathrm{Ph}$ & & & $\mathrm{x}$ & M.S. Sobrinho, 245 \\
\hline & lia & $\mathrm{Ch}$ & & $\mathrm{x}$ & & F.S. Araújo, 1497 \\
\hline & her & $\mathrm{Cr}$ & & $\mathrm{x}$ & & F.S. Araújo, 1323 \\
\hline & lia & $\mathrm{Ch}$ & $\mathrm{x}$ & & & F.S. Araújo, 1543 \\
\hline & lia & $\mathrm{Ph}$ & & & $\mathrm{x}$ & F.S. Araújo, 1290 \\
\hline & lia & $\mathrm{Ph}$ & & & $\mathrm{x}$ & J.R. Lima, 89 \\
\hline \multirow[t]{4}{*}{ grão-de-porco } & $\operatorname{shr}$ & $\mathrm{Ph}$ & & $\mathrm{x}$ & & F.S. Araújo, 1479 \\
\hline & lia & $\mathrm{Ph}$ & & & $\mathrm{x}$ & J.R. Lima, 13 \\
\hline & her & $\mathrm{Cr}$ & & & $\mathrm{x}$ & L.W. Lima-Verde, 1091 \\
\hline & her & $\mathrm{Cr}$ & & & $\mathrm{x}$ & F.S. Araújo, 1379 \\
\hline milho-de-cobra & her & $\mathrm{Cr}$ & $\mathrm{x}$ & & & R.C. Costa, 358 \\
\hline \multirow[t]{5}{*}{ agrião } & her & $\mathrm{Th}$ & $\mathrm{x}$ & & & F.S. Araújo, 1407 \\
\hline & her & $\mathrm{Th}$ & & $\mathrm{x}$ & & F.S. Araújo, 1503 \\
\hline & her & $\mathrm{Th}$ & & $\mathrm{x}$ & & F.S. Araújo, 1590 \\
\hline & her & $\mathrm{Th}$ & $\mathrm{x}$ & & $\mathrm{x}$ & R.C. Costa, 97 \\
\hline & her & $\mathrm{Th}$ & $\mathrm{x}$ & & & R.C. Costa, 441 \\
\hline \multirow[t]{2}{*}{ bamburral } & her & $\mathrm{Th}$ & $\mathrm{x}$ & & & R.C. Costa, 436 \\
\hline & her & $\mathrm{Th}$ & & & $\mathrm{x}$ & M.S. Sobrinho, 52 \\
\hline
\end{tabular}

Apocynaceae
Allamanda blanchetii A. DC.

Aspidosperma cuspa (Kunth) S.F. Blake ex Pittier

Aspidosperma discolor A. DC.

Aspidosperma multiflorum A. DC.

Aspidosperma pyrifolium Mart.

Aspidosperma cf. subincanum Mart. ex A. DC.

Mandevilla scabra (Hoffmanns. ex Roem. \& Schult.) K.Schum.

Mandevilla tenuifolia (J. C. Mikan) Woodson

Matelea harleyi Fontella \& Morillo

Prestonia bahiensis Müll Arg.

Secondatia floribunda A. DC.

Tabernaemontana catharinensis A. DC.

Tassadia burchelii E. Fourn.

Araceae

Scaphispatha gracilis Brongn. ex Schott

Spathicarpa hastifolia Hook.

Taccarum peregrinum (Schott) Engl.

\section{Asteraceae}

Acmella uliginosa (Sw.) Cass.

Aspilia cf. attenuata (Gardner) Baker

Aspilia bonplandiana (Gardner) S. F. Blake

Blainvillea lanceolata Baker

Blainvillea latifolia (L. f.) DC.

Blainvillea ligulata (L. f.) DC

Blainvillea rhomboidea Cass. 


\begin{tabular}{|c|c|c|c|c|c|c|c|}
\hline \multirow[t]{2}{*}{ Families/species } & \multirow[t]{2}{*}{ Common name } & \multirow[t]{2}{*}{ FC } & \multirow[t]{2}{*}{$\mathbf{F V}$} & \multicolumn{3}{|c|}{ Phytophysiognomy } & \multirow[t]{2}{*}{ Collector } \\
\hline & & & & $\mathbf{C A}$ & $\mathbf{C R}$ & DF & \\
\hline Centratherum punctatum Cass. & & her & Th & $\mathrm{x}$ & & & R.C. Costa, 456 \\
\hline Delilia biflora $(\mathrm{L}$.$) Kuntze$ & & her & Th & $\mathrm{x}$ & & & R.C. Costa, 440 \\
\hline Dissothrix imbricata (Gardner) B. L. Rob. & & her & Th & & $\mathrm{x}$ & & F.S. Araújo, 1467 \\
\hline Jaegeria hirta (Lag.) Less & & her & Th & $\mathrm{x}$ & & & S.F. Vasconcelos, $\mathrm{s} / \mathrm{n}$ \\
\hline Lagascea mollis Cav. & & her & Th & $\mathrm{x}$ & & & S.F. Vasconcelos, 12 \\
\hline Melampodium camphoratum (L. f.) Baker & & her & Th & & & $\mathrm{x}$ & F.S. Araújo, 1422 \\
\hline Melanthera latifolia (Gardner) Cabrera & & her & Th & & & $\mathrm{x}$ & Probio, s/n \\
\hline Pithecoseris pacourinoides Mart. ex DC. & & her & Th & & & $\mathrm{x}$ & M.S. Sobrinho, 109 \\
\hline Stilpnopappus sp. & & her & Th & & & $\mathrm{x}$ & M.S. Sobrinho, 84 \\
\hline Trichogonia cf. menthifolia Gardner & & her & Th & & & $\mathrm{x}$ & F.S. Araújo, 1560 \\
\hline Vernonia aff. arenaria Mart. ex DC. & & sub & $\mathrm{Ph}$ & & $\mathrm{x}$ & & F.S. Araújo, 1497 \\
\hline Vernonia obscura Less. & & $\operatorname{shr}$ & $\mathrm{Ph}$ & & & $\mathrm{x}$ & F.S. Araújo, 1450 \\
\hline Wedelia hookeriana Gardner & & her & Th & & & $\mathrm{x}$ & F.S. Araújo, 1287 \\
\hline Wedelia villosa Gardner & & sub & $\mathrm{Ch}$ & & & $\mathrm{x}$ & J.R. Lima, 85 \\
\hline \multicolumn{8}{|l|}{ Bignoniaceae } \\
\hline Anemopaegma ataidei A.Gentry & & lia & $\mathrm{Ph}$ & & & $\mathrm{x}$ & M.S. Sobrinho, 236 \\
\hline Arrabidaea caudigera (S. Moore) A.H.Gentry & & lia & $\mathrm{Ph}$ & $\mathrm{x}$ & & & R.C. Costa, 320 \\
\hline Arrabidaea chica( Humb. \& Bonpl.) Verl. & & lia & $\mathrm{Ph}$ & & $\mathrm{x}$ & & J.R. Lima, 21 \\
\hline Arrabidaea corallina (Jacq.) Sandwith & & lia & $\mathrm{Ph}$ & & & $\mathrm{x}$ & M.S. Sobrinho, 31 \\
\hline Arrabidaea dispar Bureau ex K. Schum. & & lia & $\mathrm{Ph}$ & & & $\mathrm{x}$ & J.R. Lima, 20 \\
\hline Jacaranda jasminoides (Thunb.) Sandwith & jacarandá & tre & $\mathrm{Ph}$ & & & $\mathrm{x}$ & R.C. Costa, 95 \\
\hline Pithecoctenium crucigerum (L.) A.H. Gentry & pente-de-macaco & lia & $\mathrm{Ph}$ & & & $\mathrm{x}$ & M.S. Sobrinho, 231 \\
\hline Tabebuia impetiginosa (Mart. ex DC.) Standl. & pau-d'arco-roxo & tre & $\mathrm{Ph}$ & $\mathrm{x}$ & & & Observada \\
\hline Tabebuia ochracea (Cham.) Standl. & pau-d'arco & tre & $\mathrm{Ph}$ & & & $\mathrm{x}$ & J.R. Lima, 23 \\
\hline \multicolumn{8}{|l|}{ Bixaceae } \\
\hline Cochlospermum vitifolium (Willd.) Spreng. & pacotê & tre & $\mathrm{Ph}$ & $\mathrm{x}$ & & $\mathrm{x}$ & S.F. Vasconcelos, 4 \\
\hline \multicolumn{8}{|l|}{ Boraginaceae } \\
\hline Cordia leucomalloides Taroda & maria-preta & $\operatorname{shr}$ & $\mathrm{Ph}$ & & $\mathrm{x}$ & $\mathrm{x}$ & L.W. Lima-Verde, 1181 \\
\hline Cordia oncocalyx Allemão & pau-branco & tre & $\mathrm{Ph}$ & $\mathrm{x}$ & & & R.C. Costa, 404 \\
\hline Cordia rufescens A. DC. & grão-de-galo & $\operatorname{shr}$ & $\mathrm{Ph}$ & & $\mathrm{x}$ & $\mathrm{x}$ & F.S. Araújo, 1478 \\
\hline Tournefortia sp. & & lia & $\mathrm{Ph}$ & & & $\mathrm{x}$ & F.S. Araújo, 1329 \\
\hline
\end{tabular}




\begin{tabular}{|c|c|c|c|c|c|c|c|}
\hline \multirow[t]{2}{*}{ Families/species } & \multirow[t]{2}{*}{ Common name } & \multirow[t]{2}{*}{ FC } & \multirow[t]{2}{*}{ FV } & \multicolumn{3}{|c|}{ Phytophysiognomy } & \multirow[t]{2}{*}{ Collector } \\
\hline & & & & $\mathbf{C A}$ & $\mathbf{C R}$ & DF & \\
\hline \multicolumn{8}{|l|}{ Brassicaceae } \\
\hline Brassica sp. & & her & $\mathrm{Th}$ & $\mathrm{x}$ & & & F.S. Araújo, 1401 \\
\hline \multicolumn{8}{|l|}{ Bromeliaceae } \\
\hline Bromelia auriculata L.B.Sm. & macambirinha & her & $\mathrm{Ch}$ & & & $\mathrm{x}$ & L.W. Lima-Verde, 1222 \\
\hline Bromelia laciniosa Mart. ex Schult. f. & macambira & her & $\mathrm{Ch}$ & & $\mathrm{x}$ & & L.W. Lima-Verde, 1216 \\
\hline Bromelia plumieri (E. Morren ) L.B.Sm. & croatá & her & $\mathrm{Ch}$ & $\mathrm{x}$ & $\mathrm{x}$ & $\mathrm{x}$ & L.W. Lima-Verde, 983 \\
\hline Encholirium erectiflorum L. B. Sm. & macambira-de-flexa & her & $\mathrm{Ch}$ & & $\mathrm{x}$ & & L.W. Lima-Verde, 981 \\
\hline \multicolumn{8}{|l|}{ Burseraceae } \\
\hline Commiphora leptophloeos (Mart.) J.B. Gillett & imburana-de-espinho & tre & $\mathrm{Ph}$ & $\mathrm{x}$ & & $\mathrm{x}$ & J.R. Lima, 48 \\
\hline \multicolumn{8}{|l|}{ Cactaceae } \\
\hline Cereus albicaulis (Britton \& Rose) Luetzelb. & rabo-de-raposa & $\operatorname{shr}$ & $\mathrm{Ph}$ & & $\mathrm{x}$ & & Observada \\
\hline Cereus jamacaru DC. & mandacaru & tre & $\mathrm{Ph}$ & $\mathrm{x}$ & $\mathrm{x}$ & $\mathrm{x}$ & Observada \\
\hline \multicolumn{8}{|l|}{ Capparaceae } \\
\hline Cynophalla flexuosa (L.) J. Presl & feijão-bravo & $\operatorname{shr}$ & $\mathrm{Ph}$ & $\mathrm{x}$ & & & Observada \\
\hline Crateva tapia $\mathrm{L}$. & trapiá & tre & $\mathrm{Ph}$ & $\mathrm{x}$ & & & Probio, 563 \\
\hline \multicolumn{8}{|l|}{ Celastraceae } \\
\hline Maytenus sp. & & tre & $\mathrm{Ph}$ & & & $\mathrm{x}$ & J.R. Lima 100 \\
\hline \multicolumn{8}{|l|}{ Chrysobalanaceae } \\
\hline Licania sclerophylla (Hook. f.) Fritsch & oiticica & tre & $\mathrm{Ph}$ & $\mathrm{x}$ & & & Probio, 327 \\
\hline \multicolumn{8}{|l|}{ Cleomaceae } \\
\hline Cleome microcarpa Ule & & her & $\mathrm{Th}$ & $\mathrm{x}$ & & & Probio, 204 \\
\hline \multicolumn{8}{|l|}{ Combretaceae } \\
\hline Buchenavia capitata (Vahl) Eichler & mirindiba & tre & $\mathrm{Ph}$ & & & $\mathrm{x}$ & M.S. Sobrinho, 292 \\
\hline Combretum glaucocarpum Mart. & cipaúba & tre & $\mathrm{Ph}$ & & & $\mathrm{x}$ & L.W. Lima-Verde, 1111 \\
\hline Combretum lanceolatum Pohl ex Eichler & catinga-branca & $\operatorname{shr}$ & $\mathrm{Ph}$ & & $\mathrm{x}$ & & Probio, 326 \\
\hline Combretum leprosum Mart. & mofumbo & $\operatorname{shr}$ & $\mathrm{Ph}$ & $\mathrm{x}$ & & $\mathrm{x}$ & F.S. Araújo, 1516 \\
\hline Combretum mellifluum Eichler & catinga-branca & $\operatorname{shr}$ & $\mathrm{Ph}$ & & $\mathrm{x}$ & & F.S. Araújo, 1473 \\
\hline \multicolumn{8}{|l|}{ Commelinaceae } \\
\hline Callisia filiformis (M. Martens \& Galeotti) D. R. Hunt & & her & $\mathrm{Th}$ & $\mathrm{x}$ & & & F.S. Araújo, 1404 \\
\hline Commelina nudiflora $\mathrm{L}$. & & her & $\mathrm{Th}$ & $\mathrm{x}$ & & & R.C. Costa, 367 \\
\hline Dichorisandra hexandra (Aubl.) Standl. & & her & $\mathrm{Th}$ & & $\mathrm{x}$ & & F.S. Araújo, 1393 \\
\hline Dichorisandra sp. & & her & $\mathrm{Th}$ & $\mathrm{x}$ & & & R.C. Costa, 395 \\
\hline
\end{tabular}




\begin{tabular}{|c|c|c|c|c|c|c|c|}
\hline \multirow[t]{2}{*}{ Families/species } & \multirow[t]{2}{*}{ Common name } & \multirow[t]{2}{*}{ FC } & \multirow[t]{2}{*}{ FV } & \multicolumn{3}{|c|}{ Phytophysiognomy } & \multirow[t]{2}{*}{ Collector } \\
\hline & & & & $\mathbf{C A}$ & CR & DF & \\
\hline \multicolumn{8}{|l|}{ Convolvulaceae } \\
\hline Evolvulus elaeagnifolius Dammer & & lia & $\mathrm{Ch}$ & & $\mathrm{x}$ & $\mathrm{x}$ & F.S. Araújo, 1486 \\
\hline Evolvulus ericaefolius Schrank. & & her & Th & $\mathrm{x}$ & & & F.S. Araújo, 1351 \\
\hline Evolvulus filipes Mart. & & her & Th & $\mathrm{x}$ & & $\mathrm{x}$ & F.S. Araújo, 1515 \\
\hline Evolvulus cf. latifolius Ker Gawl. & & her & $\mathrm{H}$ & & $\mathrm{x}$ & & F.S. Araújo, 1509 \\
\hline Evolvulus macroblepharis Mart. & & sub & $\mathrm{Ch}$ & & & $\mathrm{x}$ & J.R. Lima, 83 \\
\hline Evolvulus ovatus Fernald & & her & Th & $\mathrm{x}$ & & $\mathrm{x}$ & F.S. Araújo, 1523 \\
\hline Evolvulus pterocaulon Moric. & & sub & $\mathrm{Ch}$ & & & $\mathrm{x}$ & M.S. Sobrinho, 268 \\
\hline Evolvulus sp. & & sub & $\mathrm{Ch}$ & & $\mathrm{x}$ & & F.S. Araújo, 1395 \\
\hline Ipomoea asarifolia (Desr.) Roem. \& Schult. & & sub & $\mathrm{Ch}$ & & & $\mathrm{x}$ & M.S. Sobrinho, 283 \\
\hline Ipomoea bahiensis Willd. ex Roem. \& Schult. & jitirana-da-folha-pequena & lia & $\mathrm{Ch}$ & & & $\mathrm{x}$ & F.S. Araújo, 1424 \\
\hline Ipomoea brasiliana Meins. & & lia & $\mathrm{Ph}$ & & & $\mathrm{x}$ & J.R. Lima, 25 \\
\hline Ipomoea hederifolia $\mathrm{L}$. & pimenteira & lia & $\mathrm{Ch}$ & $\mathrm{x}$ & & & R.C. Costa, 444 \\
\hline Ipomoea nil (L.) Roth & jitirana & lia & Th & $\mathrm{x}$ & & $\mathrm{x}$ & R.C. Costa, 448 \\
\hline Ipomoea polymorpha Roem. \& Schult. & & her & Th & $\mathrm{x}$ & & & F.S. Araújo, 1522 \\
\hline Ipomoea rosea Choisy & & lia & $\mathrm{Ch}$ & & & $\mathrm{x}$ & R.C. Costa, 92 \\
\hline Ipomoea sericophylla Meisn. & & sub & $\mathrm{Ch}$ & $\mathrm{x}$ & & & Vasconcelos, S. F., 7 \\
\hline Ipomoea subincana Meisn. & & lia & $\mathrm{Ch}$ & & & $\mathrm{x}$ & F.S. Araújo, 1372 \\
\hline Jacquemontia gracillima (Choisy) Hallier $\mathrm{f}$. & & her & Th & $\mathrm{x}$ & & & F.S. Araújo, 1521 \\
\hline Jacquemontia nodiflora (Desr.) G. Don & & lia & $\mathrm{Ch}$ & & & $\mathrm{x}$ & F.S. Araújo, 1370 \\
\hline Jacquemontia pentantha (Jacq.) G. Don & & lia & $\mathrm{Ch}$ & & & $\mathrm{x}$ & F.S. Araújo, 1420 \\
\hline Merremia aegyptia (L.) Urb. & jitirana & lia & Th & $\mathrm{x}$ & & & Costa, R. C., 453 \\
\hline Operculina alata Urb. & batata-de-purga & lia & $\mathrm{Ph}$ & $\mathrm{x}$ & & & S.F. Vasconcelos, 5 \\
\hline \multicolumn{8}{|l|}{ Cucurbitaceae } \\
\hline Cayaponia racemosa (Mill.) Cogn. & & lia & $\mathrm{Ch}$ & & & $\mathrm{x}$ & M.S. Sobrinho, 183 \\
\hline \multicolumn{8}{|l|}{ Cyperaceae } \\
\hline Cyperus aggregatus (Willd.) Endl. & & her & $\mathrm{H}$ & & & $\mathrm{x}$ & J.R. Lima, 106 \\
\hline Cyperus laxus Lam. & & her & $\mathrm{H}$ & & & $\mathrm{x}$ & F.S. Araújo, 1363 \\
\hline Cyperus surinamensis Rottb. & & her & Th & $\mathrm{x}$ & & & L.W. Lima-Verde, 1092 \\
\hline Cyperus uncinulatus Schrad. ex Nees & barba de bode & her & Th & $\mathrm{x}$ & & & R.C. Costa, 361 \\
\hline Kyllinga sp. & & her & $\mathrm{H}$ & & & $\mathrm{x}$ & L.W. Lima-Verde, 1078 \\
\hline Rhynchospora sp. & & her & Th & $\mathrm{x}$ & & & Probio, 199 \\
\hline
\end{tabular}




\begin{tabular}{|c|c|c|c|c|c|c|c|}
\hline \multirow[t]{2}{*}{ Families/species } & \multirow[t]{2}{*}{ Common name } & \multirow[t]{2}{*}{ FC } & \multirow[t]{2}{*}{ FV } & \multicolumn{3}{|c|}{ Phytophysiognomy } & \multirow[t]{2}{*}{ Collector } \\
\hline & & & & $\mathbf{C A}$ & $\mathbf{C R}$ & DF & \\
\hline \multicolumn{8}{|l|}{ Dilleniaceae } \\
\hline Davilla cearensis Huber & & lia & $\mathrm{Ch}$ & & & $\mathrm{x}$ & M.S. Sobrinho, 267 \\
\hline \multicolumn{8}{|l|}{ Dioscoreaceae } \\
\hline Dioscorea ovata Vell. & & lia & $\mathrm{Cr}$ & & $\mathrm{x}$ & & F.S. Araújo, 1482 \\
\hline Dioscorea $\mathrm{sp} .1$ & & lia & $\mathrm{Cr}$ & $\mathrm{x}$ & & & R.C. Costa, 366 \\
\hline Dioscorea sp.2 & & lia & $\mathrm{Cr}$ & & & $\mathrm{x}$ & R.C. Costa, 55 \\
\hline \multicolumn{8}{|l|}{ Eriocaulaceae } \\
\hline Syngonanthus sp. & & her & $\mathrm{Th}$ & & $\mathrm{x}$ & & F.S. Araújo, 1498 \\
\hline \multicolumn{8}{|l|}{ Erythroxylaceae } \\
\hline Erythroxylum amplifolium Baill. & & $\operatorname{shr}$ & $\mathrm{Ph}$ & & & $\mathrm{x}$ & R.C. Costa, 89 \\
\hline Erythroxylum barbatum O. E. Schulz & & $\operatorname{shr}$ & $\mathrm{Ph}$ & & $\mathrm{x}$ & $\mathrm{x}$ & F.S. Araújo, 1306 \\
\hline Erythroxylum bezerrae Plowman & & $\operatorname{shr}$ & $\mathrm{Ph}$ & & $\mathrm{x}$ & $\mathrm{x}$ & F.S. Araújo, 1322 \\
\hline Erythroxylum laetevirens O. E. Schulz & pirunga & $\operatorname{shr}$ & $\mathrm{Ph}$ & & $\mathrm{x}$ & $\mathrm{x}$ & F.S. Araújo, 1472 \\
\hline Erythroxylum nummularia Peyr. & & $\operatorname{shr}$ & $\mathrm{Ph}$ & & & $\mathrm{x}$ & L.W. Lima-Verde, 952 \\
\hline Erythroxylum stipulosum Plowaman & & $\operatorname{shr}$ & $\mathrm{Ph}$ & & & $\mathrm{x}$ & L.W. Lima-Verde, 1114 \\
\hline Erythroxylum vacciniifolium Mart. & & $\operatorname{shr}$ & $\mathrm{Ph}$ & & & $\mathrm{x}$ & L.W. Lima-Verde, 952 \\
\hline \multicolumn{8}{|l|}{ Euphorbiaceae } \\
\hline Acalypha multicaulis Müll. Arg. & & sub & $\mathrm{Ch}$ & & & $\mathrm{x}$ & F.S. Araújo, 1365 \\
\hline Actinostemon sp. & & $\operatorname{shr}$ & $\mathrm{Ph}$ & & & $\mathrm{x}$ & L.W. Lima-Verde, 1199 \\
\hline Bernardia sidoides (Klotzsch) Müll. Arg. & & her & $\mathrm{Th}$ & $\mathrm{x}$ & & & F.S. Araújo, 1339 \\
\hline Chamaesyce hyssopifolia (L.) Small & & her & $\mathrm{H}$ & $\mathrm{x}$ & & & F.S. Araújo, 1342 \\
\hline Cnidoscolus vitifolius (Mill.) Pohl & cansanção & $\operatorname{shr}$ & $\mathrm{Ph}$ & & $\mathrm{x}$ & $\mathrm{x}$ & F.S. Araújo, 1309 \\
\hline Croton adenocalyx Baill. & catinga branca & $\operatorname{shr}$ & $\mathrm{Ph}$ & $\mathrm{x}$ & & & F.S. Araújo, 1346Croton \\
\hline Croton argyrophylloides Müll Arg. & marmeleiro branco & $\operatorname{shr}$ & $\mathrm{Ph}$ & & $\mathrm{x}$ & $\mathrm{x}$ & F.S. Araújo, 1294 \\
\hline Croton betaceus Baill. & & $\operatorname{shr}$ & $\mathrm{Ph}$ & & & $\mathrm{x}$ & F.S. Araújo, 1331 \\
\hline Croton blanchetianus Baill. & $\begin{array}{l}\text { marmeleiro-preto, } \\
\text { marmeleiro }\end{array}$ & $\operatorname{shr}$ & $\mathrm{Ph}$ & $\mathrm{x}$ & & $\mathrm{x}$ & F.S. Araújo, 1356 \\
\hline Croton cordiifolius Baill. & & $\operatorname{shr}$ & $\mathrm{Ph}$ & & $\mathrm{x}$ & $\mathrm{x}$ & F.S. Araújo, 1280 \\
\hline Croton echioides Müll. Arg. & & $\operatorname{shr}$ & $\mathrm{Ph}$ & & & $\mathrm{x}$ & F.S. Araújo, 1454 \\
\hline Croton glandulosus L. & & her & Th & $\mathrm{x}$ & & & Probio, 208 \\
\hline Croton grewioides Baill. & canelinha & $\operatorname{shr}$ & $\mathrm{Ph}$ & & $\mathrm{x}$ & $\mathrm{x}$ & J.R. Lima, 79 \\
\hline Croton heliotropiifolius Kunth & velame & $\operatorname{shr}$ & $\mathrm{Ph}$ & & $\mathrm{x}$ & & F.S. Araújo, 1310 \\
\hline
\end{tabular}




\begin{tabular}{|c|c|c|c|c|c|c|c|}
\hline \multirow[t]{2}{*}{ Families/species } & \multirow[t]{2}{*}{ Common name } & \multirow[t]{2}{*}{ FC } & \multirow[t]{2}{*}{ FV } & \multicolumn{3}{|c|}{ Phytophysiognomy } & \multirow[t]{2}{*}{ Collector } \\
\hline & & & & CA & CR & DF & \\
\hline Croton jacobinensis Baill. & & $\operatorname{shr}$ & $\mathrm{Ph}$ & & & $\mathrm{x}$ & L.W. Lima-Verde, 1044 \\
\hline Croton lundianus (Didr.) Müll. Arg. & & her & Th & $\mathrm{x}$ & & & R.C. Costa, 350 \\
\hline Croton moritibensis Baill. & & $\operatorname{shr}$ & $\mathrm{Ph}$ & & & $\mathrm{x}$ & L.W. Lima-Verde, 077 \\
\hline Croton nepetifolius Baill. & marmeleiro-cravinho & $\operatorname{shr}$ & $\mathrm{Ph}$ & & & $\mathrm{x}$ & F.S. Araújo, 1325 \\
\hline Croton odontadenius Müll. Arg. & & $\operatorname{shr}$ & $\mathrm{Ph}$ & & & $\mathrm{x}$ & Probio 393 \\
\hline Croton rudolphianus Müll. Arg. & & $\operatorname{shr}$ & $\mathrm{Ph}$ & & $\mathrm{x}$ & $\mathrm{x}$ & F.S. Araújo, 1325 \\
\hline Croton urticifolius Lam. & & her & Th & & $\mathrm{x}$ & & F.S. Araújo, 1376 \\
\hline Croton zehntneri Pax \& K. Hoffm. & canelinha & $\operatorname{shr}$ & $\mathrm{Ph}$ & & $\mathrm{x}$ & $\mathrm{x}$ & Probio, 40 \\
\hline Dalechampia pernambucensis Baill. & & lia & $\mathrm{Ch}$ & & & $\mathrm{x}$ & F.S. Araújo, 1428 \\
\hline Euphorbia comosa Vell. & & sub & $\mathrm{Ch}$ & & $\mathrm{x}$ & $\mathrm{x}$ & F.S. Araújo, 1461 \\
\hline Euphorbia insulana Vell. & & her & Th & $\mathrm{x}$ & & & S.F. Vasconcelos, s/n \\
\hline Gymnanthes sp1. & & $\operatorname{shr}$ & $\mathrm{Ph}$ & & & $\mathrm{x}$ & J.R. Lima, 29 \\
\hline Gymnanthes sp2. & & tre & $\mathrm{Ph}$ & & & $\mathrm{x}$ & J.R. Lima, 27 \\
\hline Gymnanthes sp3. & & $\operatorname{shr}$ & $\mathrm{Ph}$ & & $\mathrm{x}$ & $\mathrm{x}$ & M.S. Sobrinho, 8 \\
\hline Jatropha mollissima (Pohl) Baill. & pinhão & tre & $\mathrm{Ph}$ & $\mathrm{x}$ & & & R.C. Costa, 350 \\
\hline Manihot anomala Pohl & maniçoba & $\operatorname{shr}$ & $\mathrm{Ph}$ & & $\mathrm{x}$ & & F.S. Araújo, 1318 \\
\hline Manihot glaziovii Müll. Arg. & & $\operatorname{shr}$ & $\mathrm{Ph}$ & & & $\mathrm{x}$ & L.W. Lima-Verde, 1203 \\
\hline Manihot palmata Müll. Arg. & maniçoba & $\operatorname{shr}$ & $\mathrm{Ph}$ & & & $\mathrm{x}$ & F.S. Araújo, 1305 \\
\hline Maprounea sp. & & tre & $\mathrm{Ph}$ & & $\mathrm{x}$ & $\mathrm{x}$ & Probio, 273 \\
\hline Microstachys corniculata (Vahl) Griseb. & & her & Th & & $\mathrm{x}$ & & F.S. Araújo, 1470 \\
\hline Poinsettia heterophylla (L.) Klotzsch \& Garcke & & her & $\mathrm{Th}$ & $\mathrm{x}$ & & & F.S. Araújo, 1531 \\
\hline Sapium lanceolatum (Müll. Arg.) Huber & burra-leiteira & tre & $\mathrm{Ph}$ & & $\mathrm{x}$ & $\mathrm{x}$ & Probio, 14 \\
\hline Stillingia trapezoidea Ule & & $\operatorname{shr}$ & $\mathrm{Ph}$ & & $\mathrm{x}$ & & F.S. Araújo, 1321 \\
\hline Tragia cf. lessertiana (Baill.) Müll. Arg. & & lia & $\mathrm{Ch}$ & & & $\mathrm{x}$ & M.S. Sobrinho, 54 \\
\hline \multicolumn{8}{|l|}{ Fabaceae } \\
\hline \multicolumn{8}{|l|}{ Caesalpinioideae } \\
\hline Bauhinia acuruana Moric. & & $\operatorname{shr}$ & $\mathrm{Ph}$ & & $\mathrm{x}$ & & Probio, 408 \\
\hline Bauhinia cf. dubia G. Don. & & tre & $\mathrm{Ph}$ & & & $\mathrm{x}$ & J.R. Lima, 44 \\
\hline Bauhinia cheilantha (Bong.) Steud. & mororó & $\operatorname{shr}$ & $\mathrm{Ph}$ & $\mathrm{x}$ & & & F.S. Araújo, 1397 \\
\hline Bauhinia pentandra (Bong.) Vogel ex Steud. & & tre & $\mathrm{Ph}$ & $\mathrm{x}$ & & & F.S. Araújo, 1411 \\
\hline Bauhinia pulchella Benth. & mororó & tre & $\mathrm{Ph}$ & & & $\mathrm{x}$ & F.S. Araújo, 1563 \\
\hline Bauhinia ungulata L. & mororó & tre & $\mathrm{Ph}$ & & & $\mathrm{x}$ & F.S. Araújo, 1569 \\
\hline
\end{tabular}




\begin{tabular}{|c|c|c|c|c|c|c|c|}
\hline \multirow[t]{2}{*}{ Families/species } & \multirow[t]{2}{*}{ Common name } & \multirow[t]{2}{*}{ FC } & \multirow[t]{2}{*}{ FV } & \multicolumn{3}{|c|}{ Phytophysiognomy } & \multirow[t]{2}{*}{ Collector } \\
\hline & & & & CA & $\mathbf{C R}$ & DF & \\
\hline \multicolumn{2}{|l|}{ Chamaecrista barbata (Nees \& C. Mart.) H.S. Irwin \& Barneby } & sub & $\mathrm{Ch}$ & & & $\mathrm{x}$ & F.S. Araújo, 1573 \\
\hline \multicolumn{2}{|l|}{ Chamaecrista belemii (H. S. Irwin \& Barneby) } & sub & $\mathrm{Ch}$ & & $\mathrm{x}$ & & F.S. Araújo, 1388 \\
\hline \multicolumn{2}{|l|}{ Chamaecrista calycioides (Collad.) Greene } & her & $\mathrm{H}$ & $\mathrm{x}$ & & & Probio, 176 \\
\hline \multicolumn{2}{|c|}{ Chamaecrista diphylla (L.) Greene } & her & $\mathrm{H}$ & & $\mathrm{x}$ & & F.S. Araújo, 1492 \\
\hline \multicolumn{2}{|c|}{ Chamaecrista duckeana (P.Bezerra \& Afr.Fern.) H.S. Irwin \& Barneby canafístula-brava } & sub & $\mathrm{Ch}$ & $\mathrm{x}$ & & $\mathrm{x}$ & R.C. Costa, 442 \\
\hline \multicolumn{2}{|c|}{ Chamaecrista nictitans $(\mathrm{L}$.$) Moench$} & sub & $\mathrm{Ch}$ & $\mathrm{x}$ & $\mathrm{x}$ & $\mathrm{x}$ & F.S. Araújo, 1368 \\
\hline \multicolumn{2}{|l|}{ Chamaecrista ramosa (Vogel) H. S. Irwin \& Barneby } & sub & $\mathrm{Ch}$ & & & $\mathrm{x}$ & S.F. Vasconcelos, s/n \\
\hline \multicolumn{2}{|l|}{ Chamaecrista repens (Vogel) H.S.Irwin \& Barneby } & sub & $\mathrm{Ch}$ & & $\mathrm{x}$ & & F.S. Araújo, 1484 \\
\hline \multicolumn{2}{|l|}{ Chamaecrista rotundifolia (Pers.) Greene } & her & $\mathrm{Hh}$ & $\mathrm{x}$ & & & F.S. Araújo, 1410 \\
\hline \multicolumn{2}{|l|}{ Chamaecrista supplex (Benth.) Britton \& Rose ex Britton \& Killip } & her & $\mathrm{Hh}$ & $\mathrm{x}$ & & & F.S. Araújo, 1526 \\
\hline \multicolumn{2}{|l|}{ Chamaecrista tenuisepala (Benth.) H.S.Irwin \& Barneby } & sub & $\mathrm{Ch}$ & & $\mathrm{x}$ & & F.S. Araújo, 1390 \\
\hline \multicolumn{2}{|l|}{ Chamaecrista zygophylloides (Taub.) H.S. Irwin \& Barneby } & sub & $\mathrm{Ch}$ & & & $\mathrm{x}$ & M.S. Sobrinho, 112 \\
\hline Copaifera martii Hayne & pau d'óleo & tre & $\mathrm{Ph}$ & & $\mathrm{x}$ & $\mathrm{x}$ & M.S. Sobrinho, 57 \\
\hline Hymenaea eriogyne Benth. & jatobá-batinga & $\operatorname{shr}$ & $\mathrm{Ph}$ & & $\mathrm{x}$ & $\mathrm{x}$ & F.S. Araújo, 1383 \\
\hline Hymenaea velutina Ducke & $\begin{array}{l}\text { jatobá-de-porco, } \\
\text { jatobá-de-veia }\end{array}$ & tre & $\mathrm{Ph}$ & & $\mathrm{x}$ & $\mathrm{x}$ & F.S. Araújo, 1387 \\
\hline Libidibia ferrea (Mart. ex Tul.) L.P.Queiroz & jucá, pau-ferro & tre & $\mathrm{Ph}$ & $\mathrm{x}$ & & & F.S. Araújo, 1555 \\
\hline \multicolumn{2}{|l|}{ Peltogyne confertiflora (Mart. ex Hayne) Benth. } & tre & $\mathrm{Ph}$ & & & $\mathrm{x}$ & J.R. Lima, 50 \\
\hline Poincianella bracteosa (Tul.) L.P.Queiroz & catingueira & tre & $\mathrm{Ph}$ & $\mathrm{x}$ & & & R.C. Costa, 401 \\
\hline & tre & $\mathrm{Ph}$ & $\mathrm{x}$ & & & F.S. Araújo, 1538 \\
\hline \multicolumn{2}{|l|}{$\begin{array}{l}\text { Senclanella garaneriana (Bentn.) L.P.Queiroz } \\
\text { Senns cearensis Afr. Fern. }\end{array}$} & $\operatorname{shr}$ & $\mathrm{Ph}$ & & $\mathrm{x}$ & $\mathrm{x}$ & J. R. Lima, 46 \\
\hline \multicolumn{2}{|l|}{ Senna gardneri (Benth.) H. S. Irwin \& Barneby } & $\operatorname{shr}$ & $\mathrm{Ph}$ & & $\mathrm{x}$ & & R.C. Costa, 291 \\
\hline \multirow{2}{*}{$\begin{array}{l}\text { Senna lechriosperma H. S. Irwin \& Barneby } \\
\text { Senna macranthera ( DC.ex Collad.) H. S. Irwin \& Barneby }\end{array}$} & besouro & $\operatorname{shr}$ & $\mathrm{Ph}$ & & $\mathrm{x}$ & $\mathrm{x}$ & F.S. Araújo, 1382 \\
\hline & besouro & $\operatorname{shr}$ & $\mathrm{Ph}$ & & $\mathrm{x}$ & & F.S. Araújo, s/n \\
\hline \multicolumn{2}{|l|}{ Senna obtusifolia (L.) H. S. Irwin \& Barneby } & sub & $\mathrm{Ch}$ & $\mathrm{x}$ & & & Probio, 365 \\
\hline \multicolumn{2}{|l|}{ Senna rugosa (G. Don) H. S. Irwin \& Barneby } & $\operatorname{shr}$ & $\mathrm{Ph}$ & & $\mathrm{x}$ & $\mathrm{x}$ & R.C. Costa, 308 \\
\hline \multicolumn{2}{|l|}{ Senna splendida (Vogel) H.S.Irwin \& Barneby } & $\operatorname{shr}$ & $\mathrm{Ph}$ & & & $\mathrm{x}$ & F.S. Araújo, 1566 \\
\hline \multicolumn{2}{|l|}{ Senna trachypus (Mart. ex Benth.) H. S. Irwin \& Barneby } & $\operatorname{shr}$ & $\mathrm{Ph}$ & $\mathrm{x}$ & $\mathrm{x}$ & $\mathrm{x}$ & R.C. Costa, 165 \\
\hline \multicolumn{8}{|l|}{ Mimosoideae } \\
\hline Anadenanthera colubrina var. cebil (Griseb.) Altschul & angico & tre & $\mathrm{Ph}$ & $\mathrm{x}$ & & & R. C. Costa, 562 \\
\hline Chloroleucon acacioides (Ducke) Barneby \& J. W. Grimes & arapiraca & tre & $\mathrm{Ph}$ & & & $\mathrm{x}$ & R.C. Costa, 319 \\
\hline Inga ingoides (Rich.) Willd. & & tre & $\mathrm{Ph}$ & & & $\mathrm{x}$ & L.W. Lima-Verde, 1083 \\
\hline
\end{tabular}




\begin{tabular}{|c|c|c|c|c|c|c|c|}
\hline \multirow[t]{2}{*}{ Families/species } & \multirow[t]{2}{*}{ Common name } & \multirow[t]{2}{*}{ FC } & \multirow[t]{2}{*}{ FV } & \multicolumn{3}{|c|}{ Phytophysiognomy } & \multirow[t]{2}{*}{ Collector } \\
\hline & & & & CA & $\mathbf{C R}$ & DF & \\
\hline Mimosa acutistipula (Mart.) Benth. & & tre & $\mathrm{Ph}$ & & $\mathrm{x}$ & $\mathrm{x}$ & F.S. Araújo, 1476 \\
\hline Mimosa caesalpiniifolia Benth. & sabiá & tre & $\mathrm{Ph}$ & $\mathrm{x}$ & & & R.C. Costa, 399 \\
\hline Mimosa invisa Mart. ex Colla & malícia & $\operatorname{shr}$ & $\mathrm{Ph}$ & & & $\mathrm{x}$ & M.S. Sobrinho, 27 \\
\hline Mimosa quadrivalvis var. leptocarpa (DC.) Barneby & & lia & $\mathrm{Ch}$ & & & $\mathrm{x}$ & M.S. Sobrinho, 240 \\
\hline Mimosa sensitiva $\mathrm{L}$ & & lia & $\mathrm{Ch}$ & & & $\mathrm{x}$ & F.S. Araújo, 1441 \\
\hline Mimosa tenuiflora (Willd.) Poir. & jurema-preta & shr & $\mathrm{Ph}$ & $\mathrm{x}$ & & & F.S. Araújo, 1544 \\
\hline Mimosa ursina Mart. & & sub & $\mathrm{Ch}$ & $\mathrm{x}$ & & & F.S. Araújo, 1369 \\
\hline Mimosa verrucosa Benth. & & tre & $\mathrm{Ph}$ & & $\mathrm{x}$ & $\mathrm{x}$ & F.S. Araújo, 1567 \\
\hline Parkia platycephala Benth. & faveira & tre & $\mathrm{Ph}$ & & $\mathrm{x}$ & & R.C. Costa, 286 \\
\hline Piptadenia stipulacea (Benth.) Ducke & jurema-branca & tre & $\mathrm{Ph}$ & $\mathrm{x}$ & & & F.S. Araújo, 1426 \\
\hline Pityrocarpa moniliformis (Benth.) Luckow \& Jobson & catanduva & tre & $\mathrm{Ph}$ & & $\mathrm{x}$ & $\mathrm{x}$ & F.S. Araújo, 1298 \\
\hline Senegalia langsdorffii (Benth.) Seigler \& Ebinger & jurema-de-bode & $\operatorname{shr}$ & $\mathrm{Ph}$ & & $\mathrm{x}$ & $\mathrm{x}$ & M.S. Sobrinho, 195 \\
\hline Senegalia polyphylla (DC.) Britton \& Rose & & tre & $\mathrm{Ph}$ & & & $\mathrm{x}$ & F.S. Araújo, 1328 \\
\hline Senegalia tenuifolia (L.) Britton \& Rose & & tre & $\mathrm{Ph}$ & $\mathrm{x}$ & & & Probio, 335 \\
\hline Papilionoideae & & & & & & & \\
\hline Aeschynomene histrix Poir. & & her & $\mathrm{Th}$ & $\mathrm{x}$ & & & S.F. Vasconcelos, 17 \\
\hline Aeschynomene marginata Benth. & & sub & $\mathrm{Ch}$ & & $\mathrm{x}$ & & F.S. Araújo, 1502 \\
\hline Amburana cearensis (Allemão) A.C. Sm. & $\begin{array}{l}\text { cumarú, } \\
\text { imburana-de-cheiro }\end{array}$ & tre & $\mathrm{Ph}$ & $\mathrm{x}$ & & $\mathrm{x}$ & M.S. Sobrinho, 202 \\
\hline Andira surinamensis (Bondt) Splitg. ex Pulle & & tre & $\mathrm{Ph}$ & & & $\mathrm{x}$ & M.S. Sobrinho, 285 \\
\hline Arachis dardanii Krapov. \& W.C. Gregory & mondubim & her & $\mathrm{Th}$ & $\mathrm{x}$ & & & R.C. Costa, 369 \\
\hline Bowdichia virgilioides Kunth & sucupira & tre & $\mathrm{Ph}$ & & & $\mathrm{x}$ & Probio, 304 \\
\hline Centrosema brasilianum (L.) Benth. & feijão-de-rolinha & lia & $\mathrm{H}$ & $\mathrm{x}$ & & $\mathrm{x}$ & R.C. Costa, 451 \\
\hline Centrosema pascuorum Mart. ex Benth. & & her & $\mathrm{Th}$ & $\mathrm{x}$ & & & F.S. Araújo, 1518 \\
\hline Cranocarpus gracilis Afr. Fern. \& P.Bezerra & & sub & $\mathrm{Ch}$ & & & $\mathrm{x}$ & F.S. Araújo, 1371 \\
\hline Cratylia mollis Mart. ex Benth. & & lia & $\mathrm{Ph}$ & & $\mathrm{x}$ & & F.S. Araújo, 1589 \\
\hline Crotalaria vitellina Ker Gawl. & & her & $\mathrm{Th}$ & & & $\mathrm{x}$ & M.S. Sobrinho, 266 \\
\hline Dalbergia cearensis Ducke & & tre & $\mathrm{Ph}$ & & & $\mathrm{x}$ & L.W. Lima-Verde, 1197 \\
\hline Desmodium distortum (Aubl.) J.F. Macbr. & & sub & $\mathrm{Ch}$ & & & $\mathrm{x}$ & M.S. Sobrinho, 271 \\
\hline Desmodium sp. 1 & & sub & $\mathrm{Ch}$ & $\mathrm{x}$ & & & Probio, 157 \\
\hline Desmodium sp. 2 & & her & $\mathrm{Th}$ & $\mathrm{x}$ & & & Probio, 172 \\
\hline Desmodium sp. 3 & & sub & $\mathrm{Ch}$ & & & $\mathrm{x}$ & Probio, 277 \\
\hline
\end{tabular}




\begin{tabular}{|c|c|c|c|c|c|c|c|}
\hline \multirow[t]{2}{*}{ Families/species } & \multirow[t]{2}{*}{ Common name } & \multirow[t]{2}{*}{ FC } & \multirow[t]{2}{*}{ FV } & \multicolumn{3}{|c|}{ Phytophysiognomy } & \multirow[t]{2}{*}{ Collector } \\
\hline & & & & CA & $\mathbf{C R}$ & DF & \\
\hline Dioclea grandiflora Mart. ex. Benth. & mucunã & lia & $\mathrm{Ph}$ & $\mathrm{x}$ & & & F.S. Araújo, 1535 \\
\hline Dioclea megacarpa Rolfe & mucunã & lia & $\mathrm{Ph}$ & & & $\mathrm{x}$ & Rabelo, J. L., 37 \\
\hline Erythrina velutina Willd. & mulungu & tre & $\mathrm{Ph}$ & $\mathrm{x}$ & & & R.C. Costa, 328 \\
\hline Galactia jussiaeana Kunth & & lia & $\mathrm{Ph}$ & & $\mathrm{x}$ & $\mathrm{x}$ & F.S. Araújo, 1586 \\
\hline Harpalyce brasiliana Benth. & & $\operatorname{shr}$ & $\mathrm{Ph}$ & & & $\mathrm{x}$ & Probio, 303 \\
\hline Indigofera suffruticosa Mill. & & sub & $\mathrm{Ch}$ & & & $\mathrm{x}$ & M.S. Sobrinho, 228 \\
\hline Lonchocarpus araripensis Benth. & & tre & $\mathrm{Ph}$ & & & $\mathrm{x}$ & J.R. Lima, 49 \\
\hline Luetzelburgia auriculata (Allemão) Ducke & pau-mocó & tre & $\mathrm{Ph}$ & & & $\mathrm{x}$ & M.S. Sobrinho, 286 \\
\hline Machaerium acutifolium Vogel & violete & tre & $\mathrm{Ph}$ & & & $\mathrm{x}$ & F.S. Araújo, 1564 \\
\hline Machaerium stipitatum (DC.) Vogel & violete & tre & $\mathrm{Ph}$ & & & $\mathrm{x}$ & L.W. Lima-Verde, 1055 \\
\hline Ormosia fastigiata Tul. & & tre & $\mathrm{Ph}$ & & & $\mathrm{x}$ & R.C. Costa, 417 \\
\hline Periandra coccinea (Schrader) Benth. & & lia & $\mathrm{Ch}$ & & & $\mathrm{x}$ & F.S. Araújo, 1419 \\
\hline Plathymenia reticulata Benth. & candeia & tre & $\mathrm{Ph}$ & & & $\mathrm{x}$ & Probio, 300, 213 \\
\hline Platypodium elegans Vogel & & $\operatorname{shr}$ & $\mathrm{Ph}$ & & & $\mathrm{x}$ & M.S. Sobrinho, 13 \\
\hline Rhynchosia phaseoloides (Sw.) DC. & & sub & $\mathrm{Ch}$ & & & $\mathrm{x}$ & M.S. Sobrinho, 181 \\
\hline Sesbania marginata Benth. & & sub & $\mathrm{Ch}$ & $\mathrm{x}$ & & & Probio, 418 \\
\hline Stylosanthes capitata Vogel & & sub & $\mathrm{Ch}$ & & & $\mathrm{x}$ & M.S. Sobrinho, 51 \\
\hline Stylosanthes humilis Kunth & & her & Th & $\mathrm{x}$ & & & S.F. Vasconcelos, 16 \\
\hline Swartzia flaemingii Raddi & $\begin{array}{l}\text { jacarandá, } \\
\text { banha-de-galinha }\end{array}$ & tre & $\mathrm{Ph}$ & & $\mathrm{x}$ & $\mathrm{x}$ & M.S. Sobrinho, 219 \\
\hline Vatairea macrocarpa (Benth.) Ducke & & tre & $\mathrm{Ph}$ & & & $\mathrm{x}$ & M.S. Sobrinho, 293 \\
\hline \multicolumn{8}{|l|}{ Iridaceae } \\
\hline Herbertia sp. & & her & $\mathrm{Cr}$ & & & $\mathrm{x}$ & F.S. Araújo, 1375 \\
\hline Nemastylis sp. & & her & $\mathrm{Cr}$ & & $\mathrm{x}$ & & F.S. Araújo, 1481 \\
\hline \multicolumn{8}{|l|}{ Lamiaceae } \\
\hline Amasonia campestris (Aubl.) Moldenke & & sub & $\mathrm{Ch}$ & & $\mathrm{x}$ & $\mathrm{x}$ & F.S. Araújo, 1289 \\
\hline Hypenia salzmannii (Benth.) Harley & & her & $\mathrm{Th}$ & & $\mathrm{x}$ & & F.S. Araújo, 1501 \\
\hline Hyptis platanifolia Mart. ex Benth. & & her & $\mathrm{Th}$ & & & $\mathrm{x}$ & M.S. Sobrinho, 118 \\
\hline Hyptis simulans Epling & & her & Th & & & $\mathrm{x}$ & F.S. Araújo, 1570 \\
\hline Hyptis suaveolens (L.) Poit. & alfazema-brava, alfazema & her & $\mathrm{Th}$ & & $\mathrm{x}$ & $\mathrm{x}$ & F.S. Araújo, 1421 \\
\hline Marsypianthes chamaedrys (Vahl) Kuntze & & her & $\mathrm{Th}$ & $\mathrm{x}$ & $\mathrm{x}$ & & F.S. Araújo, 1406 \\
\hline Vitex schaueriana Moldenke & mama-cachorro & tre & $\mathrm{Ph}$ & & $\mathrm{x}$ & $\mathrm{x}$ & R.C. Costa, 340 \\
\hline
\end{tabular}




\begin{tabular}{|c|c|c|c|c|c|c|c|}
\hline \multirow[t]{2}{*}{ Families/species } & \multirow[t]{2}{*}{ Common name } & \multirow[t]{2}{*}{ FC } & \multirow[t]{2}{*}{$\mathbf{F V}$} & \multicolumn{3}{|c|}{ Phytophysiognomy } & \multirow[t]{2}{*}{ Collector } \\
\hline & & & & CA & $\mathbf{C R}$ & DF & \\
\hline Loasaceae & & & & & & & \\
\hline Mentzelia fragilis Huber. & prega-prega & her & $\mathrm{Th}$ & $\mathrm{x}$ & & & R.C. Costa, 433 \\
\hline Loganiaceae & & & & & & & \\
\hline Spigelia anthelmia $\mathrm{L}$. & & her & $\mathrm{Th}$ & $\mathrm{x}$ & & & F.S. Araújo, 1338 \\
\hline Lythraceae & & & & & & & \\
\hline Cuphea campestris Koehne & & her & $\mathrm{Th}$ & & $\mathrm{x}$ & & F.S. Araújo, 1408 \\
\hline Cuphea circaeoides Sm. ex Sims & & her & $\mathrm{Th}$ & & & $\mathrm{x}$ & F.S. Araújo, 1343 \\
\hline Cuphea silvestris Vahl & & her & $\mathrm{H}$ & & $\mathrm{x}$ & & F.S. Araújo, 1324 \\
\hline Malpighiaceae & & & & & & & \\
\hline Banisteriopsis angustifolia (A. Juss.) B. Gates & & lia & $\mathrm{Ph}$ & & & $\mathrm{x}$ & Probio, 01 \\
\hline Banisteriopsis lutea (Griseb.) Cuatrec. & & lia & $\mathrm{Ph}$ & & & $\mathrm{x}$ & M.S. Sobrinho, 289 \\
\hline Banisteriopsis oxyclada (A. Juss.) B. Gates. & & lia & $\mathrm{Ph}$ & & $\mathrm{x}$ & & F.S. Araújo, 1578 \\
\hline Banisteriopsis stellaris (Griseb) B. Gates & & lia & $\mathrm{Ph}$ & & $\mathrm{x}$ & $\mathrm{x}$ & M.S. Sobrinho, 94 \\
\hline Byrsonima gardneriana A. Juss. & murici & tre & $\mathrm{Ph}$ & & $\mathrm{x}$ & $\mathrm{x}$ & M.S. Sobrinho, 251 \\
\hline Heteropterys trichanthera A. Juss. & & shr & $\mathrm{Ph}$ & $\mathrm{x}$ & & & F.S. Araújo, 1536 \\
\hline Janusia janusioides W.R. Anderson. & & lia & $\mathrm{Ph}$ & & $\mathrm{x}$ & & R.C. Costa, 80 \\
\hline Mascagnia rigida (A. Juss.) Griseb. & tingui & lia & $\mathrm{Ch}$ & $\mathrm{x}$ & & & F.S. Araújo, 1550 \\
\hline Peixotoa jussieuana Mart. ex A. Juss. & & lia & $\mathrm{Ph}$ & & & $\mathrm{x}$ & F.S. Araújo, 1373 \\
\hline Malvaceae & & & & & & & \\
\hline Corchorus hirtus L. & & her & $\mathrm{Th}$ & $\mathrm{x}$ & & & F.S. Araújo, 1444 \\
\hline Guazuma ulmifolia Lam. & mutamba & tre & $\mathrm{Ph}$ & $\mathrm{x}$ & & & Probio, 331 \\
\hline Helicteres heptandra L.B. Sm. & saca-rolha & $\operatorname{shr}$ & $\mathrm{Ph}$ & & & $\mathrm{x}$ & M.S. Sobrinho, 43 \\
\hline Helicteres muscosa Mart. & saca-rolha & shr & $\mathrm{Ph}$ & & $\mathrm{x}$ & $\mathrm{x}$ & F.S. Araújo, 1320 \\
\hline Luehea uniflora A. St.-Hil. & & tre & $\mathrm{Ph}$ & & & $\mathrm{x}$ & M.S. Sobrinho, 252 \\
\hline Melochia cf. longidentata Goldberg & & sub & $\mathrm{Ch}$ & & & $\mathrm{x}$ & M.S. Sobrinho, 273 \\
\hline Pavonia cancellata (L.) Cav. & & sub & $\mathrm{Ch}$ & $\mathrm{x}$ & & $\mathrm{x}$ & Probio, 270 \\
\hline Pavonia sp.1 & & sub & $\mathrm{Ch}$ & & & $\mathrm{x}$ & F.S. Araújo, 1559 \\
\hline Pavonia sp.2 & & sub & $\mathrm{Ch}$ & & & $\mathrm{x}$ & F.S. Araújo, 1561 \\
\hline Pavonia sp.3 & & sub & $\mathrm{Ch}$ & & & $\mathrm{x}$ & J.R. Lima, 90 \\
\hline Pseudobombax marginatum (A.St-Hil. Juss. \& Cambess.) A. Robyns & embiratanha & tre & $\mathrm{Ph}$ & $\mathrm{x}$ & & & F.S. Araújo, 1553 \\
\hline Pseudoabutilon spicatum R. E. Fr. & & her & $\mathrm{Th}$ & $\mathrm{x}$ & & $\mathrm{x}$ & F.S. Araújo, 1437 \\
\hline Sida ciliaris $\mathrm{L}$. & & sub & $\mathrm{Ch}$ & $\mathrm{x}$ & & $\mathrm{x}$ & F.S. Araújo, 1514 \\
\hline
\end{tabular}




\begin{tabular}{|c|c|c|c|c|c|c|c|}
\hline \multirow[t]{2}{*}{ Families/species } & \multirow[t]{2}{*}{ Common name } & \multirow[t]{2}{*}{ FC } & \multirow[t]{2}{*}{ FV } & \multicolumn{3}{|c|}{ Phytophysiognomy } & \multirow[t]{2}{*}{ Collector } \\
\hline & & & & CA & $\mathbf{C R}$ & DF & \\
\hline Sida galheirensis Ulbr. & & sub & $\mathrm{Ch}$ & & & $\mathrm{x}$ & F.S. Araújo, 1434 \\
\hline Sida glomerata Cav. & & sub & $\mathrm{Ch}$ & & & $\mathrm{x}$ & M.S. Sobrinho, 56 \\
\hline Sida jussieuana DC. & malva & her & $\mathrm{Th}$ & $\mathrm{x}$ & & & R.C. Costa, 454 \\
\hline Waltheria brachypetela Turcz. & & sub & $\mathrm{Ch}$ & & $\mathrm{x}$ & & F.S. Araújo, 1582 \\
\hline Waltheria ferruginea A. St.-Hil. & & $\operatorname{shr}$ & $\mathrm{Ph}$ & & & $\mathrm{x}$ & M.S. Sobrinho, 254 \\
\hline Waltheria indica $\mathrm{L}$. & & sub & $\mathrm{Ch}$ & & & $\mathrm{x}$ & M.S. Sobrinho, 261 \\
\hline Waltheria macropoda Turcz. & & sub & $\mathrm{Ch}$ & $\mathrm{x}$ & & & F.S. Araújo, 1524 \\
\hline Wissadula contracta (Link) R.E.Fr. & paco-paco & her & $\mathrm{Th}$ & $\mathrm{x}$ & $\mathrm{x}$ & & Probio, 159 \\
\hline $\begin{array}{l}\text { Marantaceae } \\
\text { Calathea villosa Lindl. }\end{array}$ & & her & $\mathrm{Cr}$ & & $\mathrm{x}$ & $\mathrm{x}$ & F.S. Araújo, 1459 \\
\hline $\begin{array}{l}\text { Meliaceae } \\
\text { Trichilia elegans A. Juss. }\end{array}$ & & $\operatorname{shr}$ & $\mathrm{Ph}$ & & $\mathrm{x}$ & $\mathrm{x}$ & J. R. Lima, 31 \\
\hline $\begin{array}{l}\text { Menispermaceae } \\
\text { Cissampelos sp. }\end{array}$ & & lia & $\mathrm{Ch}$ & & $\mathrm{x}$ & $\mathrm{x}$ & Probio, 15 \\
\hline $\begin{array}{l}\text { Moraceae } \\
\text { Brosimum gaudichaudii Trécul }\end{array}$ & inharé & tre & $\mathrm{Ph}$ & & & $\mathrm{x}$ & Probio, 306 \\
\hline Myrtaceae & & & & & & & \\
\hline Campomanesia aromatica (Aubl.) Griseb. & guabiraba & $\operatorname{shr}$ & $\mathrm{Ph}$ & & $\mathrm{x}$ & $\mathrm{x}$ & J. R. Lima, 61 \\
\hline Eugenia aff. dysenterica DC. & jacaré & tre & $\mathrm{Ph}$ & & $\mathrm{x}$ & $\mathrm{x}$ & F.S. Araújo, 1291 \\
\hline Eugenia flavescens DC. & & tre & $\mathrm{Ph}$ & & $\mathrm{x}$ & $\mathrm{x}$ & R.C. Costa, 14 \\
\hline Eugenia ligustrina (Sw.) Willd. & goiabinha & $\operatorname{shr}$ & $\mathrm{Ph}$ & & $\mathrm{x}$ & & L.W. Lima-Verde, 988 \\
\hline Eugenia piauhiensis O. Berg. & canela-de-veado & tre & $\mathrm{Ph}$ & & $\mathrm{x}$ & $\mathrm{x}$ & F.S. Araújo, 1392 \\
\hline Eugenia punicifolia (Kunth) DC. & goiabinha & tre & $\mathrm{Ph}$ & & $\mathrm{x}$ & $\mathrm{x}$ & F.S. Araújo, 1391 \\
\hline Eugenia aff. uvalha Cambess. & & $\operatorname{shr}$ & $\mathrm{Ph}$ & & & $\mathrm{x}$ & J. R. Lima, 73 \\
\hline Myrcia acutiloba O. Berg. & & $\operatorname{shr}$ & $\mathrm{Ph}$ & & $\mathrm{x}$ & & F.S. Araújo, 1594 \\
\hline Myrcia guianensis (Aubl.) DC. & & $\operatorname{shr}$ & $\mathrm{Ph}$ & & & $\mathrm{x}$ & L.W. Lima-Verde, 1102 \\
\hline Myrcia multiflora (Lam.) DC. & & $\operatorname{shr}$ & $\mathrm{Ph}$ & & & $\mathrm{x}$ & R.C. Costa, 318 \\
\hline Myrcia cf. obtecta (O. Berg) Kiaersk. & & $\operatorname{shr}$ & $\mathrm{Ph}$ & & & $\mathrm{x}$ & M.S. Sobrinho, 264 \\
\hline Myrcia sp. & & $\operatorname{shr}$ & $\mathrm{Ph}$ & & & $\mathrm{x}$ & R.C. Costa, 241 \\
\hline Nyctaginaceae & & & & & & & \\
\hline Boerhavia coccinea Mill. & pega-pinto & her & $\mathrm{H}$ & $\mathrm{x}$ & & & L.W. Lima-Verde, 1108 \\
\hline Guapira graciliflora (Schmidt) Lundell & joão-mole & $\operatorname{shr}$ & $\mathrm{Ph}$ & $\mathrm{x}$ & $\mathrm{x}$ & $\mathrm{x}$ & J.R. Lima, 34 \\
\hline
\end{tabular}




\begin{tabular}{|c|c|c|c|c|c|c|c|}
\hline \multirow[t]{2}{*}{ Families/species } & \multirow[t]{2}{*}{ Common name } & \multirow[t]{2}{*}{ FC } & \multirow[t]{2}{*}{ FV } & \multicolumn{3}{|c|}{ Phytophysiognomy } & \multirow[t]{2}{*}{ Collector } \\
\hline & & & & CA & CR & DF & \\
\hline \multicolumn{8}{|l|}{ Ochnaceae } \\
\hline Ouratea aff. disticha Tiegh & & tre & $\mathrm{Ph}$ & & & $\mathrm{x}$ & J.R. Lima, 54 \\
\hline Ouratea cf. parvifolia Engl. & & tre & $\mathrm{Ph}$ & & & $\mathrm{x}$ & J.R. Lima, 53 \\
\hline \multicolumn{8}{|l|}{ Olacaceae } \\
\hline Heisteria sp. & & $\operatorname{shr}$ & $\mathrm{Ph}$ & & $\mathrm{x}$ & $\mathrm{x}$ & Probio 285 \\
\hline Schoepfia sp. & & tre & $\mathrm{Ph}$ & & $\mathrm{x}$ & $\mathrm{x}$ & Probio 312 \\
\hline Ximenia americana $\mathrm{L}$. & ameixa & $\operatorname{shr}$ & $\mathrm{Ph}$ & & & $\mathrm{x}$ & J.R. Lima, 55 \\
\hline \multicolumn{8}{|l|}{ Onagraceae } \\
\hline Ludwigia erecta (L.) H. Hara & & her & $\mathrm{Th}$ & $\mathrm{x}$ & & & F.S. Araújo, 1540 \\
\hline \multicolumn{8}{|l|}{ Opiliaceae } \\
\hline Agonandra brasiliensis Miers ex Benth. \& Hook. f. & pau-marfim & tre & $\mathrm{Ph}$ & & $\mathrm{x}$ & $\mathrm{x}$ & M.S. Sobrinho, 294 \\
\hline \multicolumn{8}{|l|}{ Oxalidaceae } \\
\hline Oxalis divaricata Mart. ex Zucc. & & sub & $\mathrm{Ch}$ & $\mathrm{x}$ & $\mathrm{x}$ & $\mathrm{x}$ & M.S. Sobrinho, 88 \\
\hline Oxalis frutescens $\mathrm{L}$. & & sub & $\mathrm{Ch}$ & & $\mathrm{x}$ & $\mathrm{x}$ & F.S. Araújo, 1460 \\
\hline \multicolumn{8}{|l|}{ Passifloraceae } \\
\hline Passiflora cincinnata Mast. & maracujá & lia & $\mathrm{Ph}$ & & $\mathrm{x}$ & & F.S. Araújo, 1480 \\
\hline Passiflora foetida $\mathrm{L}$ & $\begin{array}{l}\text { cheira-raposa, maracujá-de- } \\
\text { raposa, maracujá-de-estalo }\end{array}$ & lia & $\mathrm{Ch}$ & $\mathrm{x}$ & & & L.W. Lima-Verde, 1210 \\
\hline Piriqueta guianensis N. E. Br. & & sub & $\mathrm{Ch}$ & $\mathrm{x}$ & & & F.S. Araújo, 1349 \\
\hline Piriqueta sidifolia (A. St.-Hil. \& A. Juss. \& Cambess.) Urb. & & sub & $\mathrm{Ch}$ & & & $\mathrm{x}$ & R.C. Costa, 66 \\
\hline Turnera blanchetiana Urb. & & $\operatorname{shr}$ & $\mathrm{Ph}$ & & & $\mathrm{x}$ & F.S. Araújo, 1283 \\
\hline Turnera coerulea Sessé \& Moc. ex DC. & chanana & sub & $\mathrm{Ch}$ & & $\mathrm{x}$ & $\mathrm{x}$ & F.S. Araújo, 1389 \\
\hline Turnera pumilea $\mathrm{L}$. & & sub & $\mathrm{Ch}$ & $\mathrm{x}$ & & & F.S. Araújo, 1336 \\
\hline Turnera subulata $\mathrm{Sm}$. & chanana & sub & $\mathrm{Ch}$ & $\mathrm{x}$ & & & F.S. Araújo, 1340 \\
\hline \multicolumn{8}{|l|}{ Plantaginaceae } \\
\hline Angelonia cornigera Hook. & & her & $\mathrm{Th}$ & & $\mathrm{x}$ & & F.S. Araújo, 1491 \\
\hline Dizygostemon floribundum (Benth.) Radlk ex. Wettst. & & her & $\mathrm{Th}$ & & $\mathrm{x}$ & & F.S. Araújo, 1493 \\
\hline Scoparia dulcis $\mathrm{L}$ & vassourinha & sub & $\mathrm{Ch}$ & $\mathrm{x}$ & & & L.W. Lima-Verde, 1193 \\
\hline \multicolumn{8}{|l|}{ Phyllanthaceae } \\
\hline Phyllanthus caroliniensis Walter & & her & $\mathrm{Th}$ & $\mathrm{x}$ & & & Probio, 202 \\
\hline Phyllanthus niruri L. & & her & $\mathrm{Th}$ & & $\mathrm{x}$ & & F.S. Araújo, 1507 \\
\hline Phyllanthus orbiculatus Rich. & & her & $\mathrm{Th}$ & $\mathrm{x}$ & & & R.C. Costa, 368 \\
\hline Phyllanthus sp. & & her & $\mathrm{Th}$ & $\mathrm{x}$ & & & R.C. Costa, 357 \\
\hline
\end{tabular}




\begin{tabular}{|c|c|c|c|c|c|c|c|}
\hline \multirow[t]{2}{*}{ Families/species } & \multirow[t]{2}{*}{ Common name } & \multirow[t]{2}{*}{ FC } & \multirow[t]{2}{*}{ FV } & \multicolumn{3}{|c|}{ Phytophysiognomy } & \multirow[t]{2}{*}{ Collector } \\
\hline & & & & CA & $\mathbf{C R}$ & DF & \\
\hline \multicolumn{8}{|l|}{ Plumbaginaceae } \\
\hline Plumbago scandens $\mathrm{L}$. & & sub & $\mathrm{Ch}$ & & & $\mathrm{x}$ & M.S. Sobrinho, 107 \\
\hline \multicolumn{8}{|l|}{ Poaceae } \\
\hline Cenchrus ciliaris L. & & her & $\mathrm{Th}$ & & & $\mathrm{x}$ & M.S. Sobrinho, 66 \\
\hline Chaetium festucoides Nees & & her & $\mathrm{Th}$ & & & $\mathrm{x}$ & M.S. Sobrinho, 93 \\
\hline Eragrostis cf. ciliaris (L.) R. Br. & & her & $\mathrm{Th}$ & $\mathrm{x}$ & & & S.F. Vasconcelos, 1 \\
\hline Lasiacis anomala Hitchc. & & her & Th & & & $\mathrm{x}$ & M.S. Sobrinho, 96 \\
\hline Panicum cf. maximum Jacq. & & her & $\mathrm{Th}$ & $\mathrm{x}$ & & & F.S. Araújo, 1403 \\
\hline Panicum sellowii Ness & & her & $\mathrm{Th}$ & & & $\mathrm{x}$ & F.S. Araújo, 1364 \\
\hline Panicum trichoides Sw. & capim & her & $\mathrm{Th}$ & $\mathrm{x}$ & $\mathrm{x}$ & $\mathrm{x}$ & R.C. Costa, 433 \\
\hline Paspalum faveolatum Steud. & & her & $\mathrm{Th}$ & $\mathrm{x}$ & & & S.F. Vasconcelos, s/n \\
\hline Paspalum plicatulum Michx. & capim & her & $\mathrm{Th}$ & $\mathrm{x}$ & & & S. F. Vasconcelos, 1402 \\
\hline Pseudechinolaena sp. & & her & $\mathrm{Th}$ & & & $\mathrm{x}$ & F.S. Araújo, 1440 \\
\hline Setaria geniculata P. Beauv. & & her & $\mathrm{Th}$ & $\mathrm{x}$ & & & S.F. Vasconcelos, s/n \\
\hline Setaria pauciflora Linden ex Herrm. & & her & $\mathrm{Th}$ & & & $\mathrm{x}$ & M.S. Sobrinho, 92 \\
\hline Setaria rariflora J.C. Mikan ex Trin. & & her & $\mathrm{Th}$ & & & $\mathrm{x}$ & M.S. Sobrinho, 38 \\
\hline Setaria cf. tenax (Rich.) Desv. & & her & $\mathrm{Th}$ & $\mathrm{x}$ & & & R.C. Costa, 396 \\
\hline Steirachne diandra Ekman & & her & $\mathrm{Th}$ & & $\mathrm{x}$ & & F.S. Araújo, 1499 \\
\hline Streptostachys asperifolia Desv. & & her & $\mathrm{Th}$ & & $\mathrm{x}$ & $\mathrm{x}$ & F.S. Araújo, 1307 \\
\hline Urochloa fasciculata (Sw.) R.D. Webster & & her & $\mathrm{Th}$ & $\mathrm{x}$ & & & L.W. Lima-Verde, 1200 \\
\hline \multicolumn{8}{|l|}{ Polygalaceae } \\
\hline Bredemeyera floribunda Willd. & & lia & $\mathrm{Ph}$ & & $\mathrm{x}$ & $\mathrm{x}$ & F.S. Araújo, 1572 \\
\hline Polygala gracilis Kunth & & her & $\mathrm{Th}$ & & & $\mathrm{x}$ & F.S. Araújo, 1385 \\
\hline Polygala paniculata $\mathrm{L}$. & & her & $\mathrm{Th}$ & & $\mathrm{x}$ & $\mathrm{x}$ & F.S. Araújo, 1384 \\
\hline Polygala violacea Aubl. & & her & $\mathrm{Th}$ & $\mathrm{x}$ & & & F.S. Araújo, 1412 \\
\hline \multicolumn{8}{|l|}{ Pontederiaceae } \\
\hline Heteranthera limosa (Sw.) Willd. & & her & $\mathrm{Ch}$ & $\mathrm{x}$ & & & F.S. Araújo, 1541 \\
\hline \multicolumn{8}{|l|}{ Portulacaceae } \\
\hline Portulaca pilosa $\mathrm{L}$ & beldroega & her & $\mathrm{Th}$ & $\mathrm{x}$ & & & L.W. Lima-Verde, 1205 \\
\hline Talinum paniculatum (Jacq.) Gaertn. & & her & $\mathrm{Th}$ & $\mathrm{x}$ & & $\mathrm{x}$ & R. C. Costa, 354 \\
\hline Talinum triangulare (Jacq.) Willd. & & her & Th & $\mathrm{x}$ & $\mathrm{x}$ & & R. C. Costa, 368 \\
\hline Rhamnaceae & & & & & & & \\
\hline
\end{tabular}

Plumbaginaceae

ago scandens

Cenchrus ciliaris L.

Panicum sellowii Nes

Pseudechinolaena sp.

Streptostachys asperifolia Desv.

\section{Polygalaceae}

Portulaca pilosa $\mathrm{L}$

Talinum paniculatum (Jacq.) Gaertn.

Rhamnaceae 


\begin{tabular}{|c|c|c|c|c|c|c|c|}
\hline \multirow[t]{2}{*}{ Families/species } & \multirow[t]{2}{*}{ Common name } & \multirow[t]{2}{*}{ FC } & \multirow[t]{2}{*}{ FV } & \multicolumn{3}{|c|}{ Phytophysiognomy } & \multirow[t]{2}{*}{ Collector } \\
\hline & & & & CA & $\mathbf{C R}$ & DF & \\
\hline Colubrina cordifolia Reissek & & $\operatorname{shr}$ & $\mathrm{Ph}$ & & $\mathrm{x}$ & $\mathrm{x}$ & M.S. Sobrinho, 248 \\
\hline Gouania colurnifolia Reissek & & lia & $\mathrm{Ph}$ & & $\mathrm{x}$ & & F.S. Araújo, 1577 \\
\hline Ziziphus joazeiro Mart. & juazeiro & tre & $\mathrm{Ph}$ & $\mathrm{x}$ & & & F.S. Araújo, 1354 \\
\hline \multicolumn{8}{|l|}{ Rubiaceae } \\
\hline Alibertia myrciifolia Spruce ex K. Schum. & & tre & $\mathrm{Ph}$ & & & $\mathrm{x}$ & J. R. Lima, 102 \\
\hline Chomelia martiana Müll. Arg. & espinho-judeu & $\operatorname{shr}$ & $\mathrm{Ph}$ & & & $\mathrm{x}$ & F.S. Araújo, 1452 \\
\hline Diodia cf. barbeyana Huber & & her & Th & & $\mathrm{x}$ & $\mathrm{x}$ & Probio, 231 \\
\hline Diodia radula (Willd. ex Roem. \& Schult.) Cham. \& Schltdl. & & sub & $\mathrm{Ch}$ & & & $\mathrm{x}$ & M.S. Sobrinho, 242 \\
\hline Faramea sp. & & tre & $\mathrm{Ph}$ & & & $\mathrm{x}$ & J.R. Lima, 104 \\
\hline Guettarda viburnoides Cham. \& Schltdl. & genipapo-bravo & $\operatorname{shr}$ & $\mathrm{Ph}$ & & $\mathrm{x}$ & & F.S. Araújo, 1299 \\
\hline $\begin{array}{l}\text { Margaritopsis carrascoana (Delprete \& E.B. Souza) } \\
\text { C.M. Taylor \& E.B. Souza }\end{array}$ & & sub & $\mathrm{Ch}$ & & $\mathrm{x}$ & $\mathrm{x}$ & F.S. Araújo, s/n \\
\hline Richardia grandiflora (Cham. \& Schltdl.) Steud. & & sub & $\mathrm{Ch}$ & & $\mathrm{x}$ & $\mathrm{x}$ & F.S. Araújo, 1591 \\
\hline Spermacoce scabiosoides (Cham. \& Schltdl.) Kuntze & & her & $\mathrm{H}$ & $\mathrm{x}$ & & & F.S. Araújo, 1399 \\
\hline Spermacoce verticillata $\mathrm{L}$. & & her & $\mathrm{H}$ & & & $\mathrm{x}$ & M.S. Sobrinho, 75 \\
\hline Spermacoce sp. & & her & Th & $\mathrm{x}$ & & & Probio, 201 \\
\hline Tocoyena formosa (Cham. \& Schltdl.) K. Schum. & jenipapo-bravo & $\operatorname{shr}$ & $\mathrm{Ph}$ & & $\mathrm{x}$ & $\mathrm{x}$ & F.S. Araújo, 1587 \\
\hline \multicolumn{8}{|l|}{ Rutaceae } \\
\hline Galipea aff. trifoliata Aubl. & & tre & $\mathrm{Ph}$ & & & $\mathrm{x}$ & J.R. Lima, 91 \\
\hline Pilocarpus spicatus Holmes & jaborandi & tre & $\mathrm{Ph}$ & & & $\mathrm{x}$ & F.S. Araújo, 1358 \\
\hline Zanthoxylum stelligerum Turcz. & limãozinho & $\operatorname{shr}$ & $\mathrm{Ph}$ & & $\mathrm{x}$ & & F.S. Araújo, 1592 \\
\hline \multicolumn{8}{|l|}{ Salicaceae } \\
\hline Xylosma ciliatifolia (Clos) Eichler & espinho-de-judeu & tre & $\mathrm{Ph}$ & & $\mathrm{x}$ & $\mathrm{x}$ & F.S. Araújo, 1301 \\
\hline \multicolumn{8}{|l|}{ Santalaceae } \\
\hline Phoradendron sp. & & hemip & $\mathrm{Ch}$ & & & $\mathrm{x}$ & M.S. Sobrinho, 257 \\
\hline \multicolumn{8}{|l|}{ Sapindaceae } \\
\hline Allophylus cf. sericeus Radlk. & mama-cachorro & $\operatorname{shr}$ & $\mathrm{Ph}$ & & & $\mathrm{x}$ & F.S. Araújo, 1360 \\
\hline Cardiospermum corindum $\mathrm{L}$. & $\begin{array}{l}\text { pau-prá-tudo, laça-vaqueiro, } \\
\text { chá-de-conhã }\end{array}$ & & $\mathrm{Ch}$ & $\mathrm{x}$ & & & F.S. Araújo, 1350 \\
\hline Magonia pubescens A.St.-Hil. & tingui-de-bola & tre & $\mathrm{Ph}$ & & $\mathrm{x}$ & $\mathrm{x}$ & F.S. Araújo, 1380 \\
\hline Matayba guianensis Aubl. & & tre & $\mathrm{Ph}$ & & & $\mathrm{x}$ & L.W. Lima-Verde, 1161 \\
\hline
\end{tabular}




\begin{tabular}{|c|c|c|c|c|c|c|c|}
\hline \multirow[t]{2}{*}{ Families/species } & \multirow[t]{2}{*}{ Common name } & \multirow[t]{2}{*}{ FC } & \multirow[t]{2}{*}{ FV } & \multicolumn{3}{|c|}{ Phytophysiognomy } & \multirow[t]{2}{*}{ Collector } \\
\hline & & & & $\mathbf{C A}$ & $\mathbf{C R}$ & DF & \\
\hline Paullinia cearensis Somner \& Ferrucci & & lia & $\mathrm{Ph}$ & & & $\mathrm{x}$ & F.S. Araújo, 1304 \\
\hline Paullinia cf. elegans Cambess. & & lia & $\mathrm{Ph}$ & & & $\mathrm{x}$ & J.R. Lima, 35 \\
\hline Sapindus saponaria $\mathrm{L}$. & sabonete & tre & $\mathrm{Ph}$ & & & $\mathrm{x}$ & F.S. Araújo, 1510 \\
\hline Serjania glabrata Kunth & & lia & $\mathrm{Ph}$ & & & $\mathrm{x}$ & M.S. Sobrinho, 290 \\
\hline Serjania lethalis A. St.-Hil. & & lia & $\mathrm{Ph}$ & & $\mathrm{x}$ & & F.S. Araújo, 1597 \\
\hline Talisia esculenta (A. St.-Hil.) Radlk. & pitomba & tre & $\mathrm{Ph}$ & & & $\mathrm{x}$ & L.W. Lima-Verde, 1139 \\
\hline Urvillea laevis Radlk. & & lia & $\mathrm{Ph}$ & & & $\mathrm{x}$ & M.S. Sobrinho, 234 \\
\hline \multicolumn{8}{|l|}{ Sapotaceae } \\
\hline Chrysophyllum arenarium Allemão & & $\operatorname{shr}$ & $\mathrm{Ph}$ & & & $\mathrm{x}$ & L.W. Lima-Verde, 1180 \\
\hline Chrysophyllum sp. & & tre & $\mathrm{Ph}$ & & $\mathrm{x}$ & & F.S. Araújo, 1588 \\
\hline Manilkara sp. & & tre & $\mathrm{Ph}$ & & & $\mathrm{x}$ & F.S. Araújo, 1557 \\
\hline \multicolumn{8}{|l|}{ Solanaceae } \\
\hline Solanum baturitense Huber & jurubeba & $\operatorname{shr}$ & $\mathrm{Ph}$ & & $\mathrm{x}$ & & F.S. Araújo, 1579 \\
\hline Solanum crinitum Lam. & jurubeba & $\operatorname{shr}$ & $\mathrm{Ph}$ & & $\mathrm{x}$ & & F.S. Araújo, 1580 \\
\hline \multicolumn{8}{|l|}{ Trigoniaceae } \\
\hline Trigonia nivea Cambess. & & lia & $\mathrm{Ph}$ & & & $\mathrm{x}$ & L.W. Lima-Verde, 1253 \\
\hline \multicolumn{8}{|l|}{ Ulmaceae } \\
\hline Trema micrantha (L.) Blume & & tre & $\mathrm{Ph}$ & & $\mathrm{x}$ & & F.S. Araújo, 1575 \\
\hline \multicolumn{8}{|l|}{ Urticaceae } \\
\hline Laportea aestuans (L.) Chew & & her & $\mathrm{Th}$ & $\mathrm{x}$ & & & Probio, 348 \\
\hline \multicolumn{8}{|l|}{ Verbenaceae } \\
\hline Lantana camara $\mathrm{L}$. & camará, chumbinho & $\operatorname{shr}$ & $\mathrm{Ph}$ & $\mathrm{x}$ & & $\mathrm{x}$ & R.C. Costa, 370 \\
\hline Lantana fucata Lindl. & & sub & $\mathrm{Ch}$ & & $\mathrm{x}$ & & F.S. Araújo, 1312 \\
\hline Lippia gracilis Schauer & & $\operatorname{shr}$ & $\mathrm{Ph}$ & & $\mathrm{x}$ & & R.C. Costa, 523 \\
\hline Lippia magentea T. Silva & & sub & $\mathrm{Ch}$ & & & $\mathrm{x}$ & F.S. Araújo, 1292 \\
\hline Stachytarpheta cayennensis (Rich.) Vahl & & her & $\mathrm{Th}$ & $\mathrm{x}$ & & & F.S. Araújo, 1398 \\
\hline \multicolumn{8}{|l|}{ Violaceae } \\
\hline Hybanthus ipecacuaha (L.) Baill. & pepaconha & her & $\mathrm{H}$ & & $\mathrm{x}$ & & F.S. Araújo, 1386 \\
\hline \multicolumn{8}{|l|}{ Vitaceae } \\
\hline Cissus gongylodes (Burk ex Baker) Planch. & & lia & $\mathrm{Ch}$ & $\mathrm{x}$ & & & R.C. Costa, 374 \\
\hline Cissus tinctoria Mart. & & lia & $\mathrm{Ch}$ & & & $\mathrm{x}$ & F.S. Araújo, 1427 \\
\hline
\end{tabular}

